\title{
A Comprehensive Review on Polymeric Nano-Composite Membranes for Water Treatment
}

Muhammad Zahid ${ }^{1}$, Anum Rashid ${ }^{1}$, Saba Akram¹, Zulfiqar Ahmad Rehan ${ }^{\star *}$ and Wasif Razzaq ${ }^{2}$

${ }^{1}$ Department of Chemistry, University of Agriculture, Faisalabad, Pakistan

${ }^{2}$ Department of Polymer Engineering, National Textile University, Faisalabad, Pakistan

\begin{abstract}
During last few decades, membrane technology has emerged as an efficient technique over conventional methods due to its high removal capacity, ease in operation and cost effectiveness for wastewater treatment and production of clean water. Membrane based separations are commonly based on polymeric membranes because of their higher flexibility, easily pore forming mechanism, low cost and smaller space for installation as compared to inorganic membranes. Commonly employed membrane fabrication phase inversion method has been shortly reviewed in this article. Major limitation of membrane based separations is fouling and polymeric membranes being hydrophobic in nature are more prone to fouling. Fouling is a deposition of various colloidal particles, macromolecules (polysaccharides, proteins), salts etc. on membrane surface and within pores thus impedes membrane performance, reduces flux and results in high cost. Modification of polymeric membranes due to its tailoring ability with nanomaterials such as metal based and carbon based results in polymeric nano-composite membranes with high antifouling characteristics. Nanomaterials impart high selectivity, permeability, hydrophilicity, thermal stability, mechanical strength, and antibacterial properties to polymeric membranes via blending, coating etc. modification methods. Characterization techniques has also discussed in later section for studying morphological properties and performance of polymer nano-composite membranes.
\end{abstract}

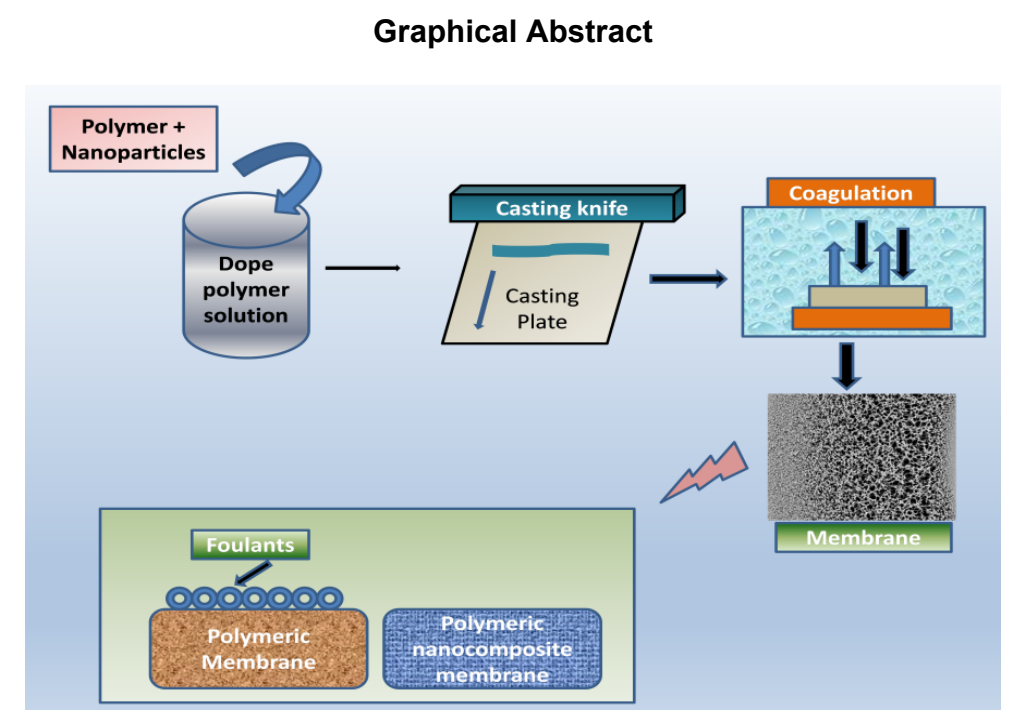

Keywords: Bovine serum albumin; Membrane technology; Osmosis; Polymer nanocomposites; Surface porosity; Hydrophilicity; Nanohybrid membrane

\section{Abbreviations}

BSA: Bovine Serum Albumin; BET: Brunauer-Emmett-Teller; BJH: Barrett-Joyner-Halenda; CA: Cellulose Acetate; CNTs: Carbon Nanotubes; CTA: Cellulose Triacetate; Da: Dalton; DOM: Dissolved Organic Matter; DMF: N,N-dimethyl Formamide; DMAc: N,NDimethyl Acetamide; DMSO: Dimethylsulfoxide; DADMAC: Diallyl Dimethyl Ammonium Chloride; DLS: Dynamic Light Scattering; ESCA: Elemental Spectroscopy for Chemical Analysis; EDX: Energy Dispersive X-Ray Spectroscopy; EIPS: Evaporation Induced Phase Inversion; FO: Forward Osmosis; FT-IR: Fourier Transform Infrared Spectroscopy; GO: Graphene Oxide; HA: Humic Acid; LLDP: Liquid Liquid Displacement Porosimetry; MBR: Membrane Bioreactors; MWCNTs: Multi Walled Carbon Nanotubes; MF: Microfiltration;
NMP: N-methyl-2-pyrrolidone; NIPS: Non-solvent Induced Phase Inversion; NPs: Nanoparticles; NOM: Natural Organic Matter; NF: Nano-filtration; NCF: Nitrocellulose Filter; PVA: Polyvinyl Alcohol; PES: Polyether Sulfone; PVDF: Polyvinylidene Fluoride; PVC: Polyvinyl Chloride; PP: Polypropyline; PAN: Polyacrylonitrile; PI: Polyimide;

*Corresponding author: Zulfiqar Ahmad Rehan, Department of Polymer Engineering, National Textile University, Faisalabad 37610, Pakistan, Tel: +92 300 984 4363; E-mail: zarehan@ntu.edu.pk

Received March 19, 2018; Accepted March 26, 2018; Published March 31, 2018

Citation: Zahid M, Rashid A, Akram S, Rehan ZA, Razzaq W (2018) A Comprehensive Review on Polymeric Nano-Composite Membranes for Water Treatment. J Membr Sci Technol 8: 179. doi:10.4172/2155-9589.1000179

Copyright: (๑) 2018 Zahid M, et al. This is an open-access article distributed under the terms of the Creative Commons Attribution License, which permits unrestricted use, distribution, and reproduction in any medium, provided the original author and source are credited. 
PE: Polyethylene; PA: Polyamide; PSf: Polysulfone; PEG: Polyethylene Glycol; PVP: Polyvinyl Pyrrolidone; PMMA: Poly Methyl Methacrylate; PEO: Poly Ethylene Oxide; RO: Reverse Osmosis; ROS: Reactive Oxygen Species; SMP: Soluble Microbial Products; SWCNTs: Single Walled Carbon Nanotubes; SEM: Scanning Electron Microscopy; TEM: Transmission Electron Microscopy; TFC: Thin Film Nano-composite; THF: Tetrahydrofuran; TIPS: Thermally Induced Phase Inversion; TGA: Thermo-Gravimetric Analysis; UF: Ultra-filtration; VIPS: Vapour Induced Phase Inversion; WHO: World Health Organization; XPS: X-Ray Photoelectron Spectroscopy; XRD: X-Ray Diffraction.

\section{Introduction}

With rapid increase in world's population, demand for drinking water has been increased up to sevenfold [1]. Within next 30 years it is expected that population will increase up to $40 \%$ and need of domestic, agriculture and industrial water sources will be increased, especially in developing countries where the need of water is greater as compared to its economic status and population [2]. According to an estimation of World Health Organization (WHO), 1.1 billion people lack access to clean drinking water [3]. By 2030 there will be a great chance of 3.9 billion people to live in 'water scarce' regions (according to a report of World Water Council) [4]. Only 0.5\% Earth's overall water resource is available for drinking purpose while rest of $97 \%$ is covered by sea water which is unfit for human consumption due to high salinity and by 2050 , according to estimation there will be a 7 to 10 billion increase in world's population [5]. In order to overcome the problem of water shortage and demand for clean drinking water, there is a need of development of new water sources and protection of existing water resources through proper strategy for water treatment [6].

Membrane technology contributes up to $53 \%$ of total world processes for production of clean water and is an effective approach for water treatment due to its simplicity in operation, no addition of chemical additives (or less), cost effective, no phase changing, high productivity, easy scaling up and high removal capacity. Due to aforementioned features, membrane technology plays an important role in treatment of brackish and wastewater, desalination of sea water (its reuse for consumption purposes), dairy industry for milk skimming and effluents treatment etc. [7-10]. A membrane can be defined as a physical barrier which selectively allows wanted materials to pass through and unwanted to retain on the membrane surface [11]. Membranes are classified into polymeric membranes and inorganic membranes. Inorganic membranes are made up of metals or ceramics exhibits high structural, mechanical and thermal strength. Although they have extremely high selectivity but their limited permeability makes them less attractive for various applications. Among inorganic membranes, micro porous silica membranes are widely used in molecular sieving applications. As many size dependent molecular filtration processes requires pore size in nanometer range which is still an issue for inorganic microporous silica membranes to obtained and has not been resolved yet. However, zeolite inorganic membranes are playing role in this context. Due to high thermal stability, hydrophilic nature zeolite membranes are used as excellent filters at molecular scale as compared to other inorganic counterparts. Although zeolite membranes are widely used in various filtration processes but features such as ion exchange capability, solid acidity, release or adsorption capacity and catalytic nature limits their application where they require as neutral filters [12].

Polymeric membranes on the other hand, due to their greater flexibility, good film forming property, mechanical strength, chemical stability, high perm selectivity, selective transfer of chemical species, inexpensive materials for its fabrications and required pore sizes for various filtration processes are on main streamline and finds their application in pressure driven processes such as Ultra-Filtration (UF), Nano-Filtration (NF), Reverse Osmosis (RO), gas separation, drug delivery and in waste water treatment [13-16]. Materials used for fabrication of polymeric membranes includes Polyvinyl Alcohol (PVA), Polyether sulfone (PES), Polyvinylidene fluoride (PVDF), Polyvinyl chloride (PVC), Polypropylene (PP), Polyacrylonitrile (PAN), Polyimide (PI), Polyethylene (PE), Polyvinyl Alcohol (PVA) Cellulose Acetate (CA), Polyamide (PA) and chitosan [17]. On the basis of pore size and filtration process, membranes are classified into four different categories such as Microfiltration (MF), Ultra filtration (UF), Nano-filtration (NF) and Reverse Osmosis (RO). Where, Microfiltration (MF) are porous membranes which exhibits pore size of $1-0.1 \mu \mathrm{m}$ for separation of particles in this range such as larger particles (colloids, macromolecules, bacteria and other particulates). UF membranes possess pore size in the range of 0.1-0.01 $\mu \mathrm{m}$ and separates out (viruses/macromolecules) and solutes of high molecular weights as retentate and allow water and low molecular weight solutes to pass within permeate. Nanofiltration (NF) membrane is a dense membrane structure with small pores as compared to UF and MF and removes (divalent ions) and allows monovalent ions to pass with a pore size range of $0.1-0.001 \mu \mathrm{m}$. Reverse Osmosis (RO) membrane are more dense membranes as compared to NF and is a high pressure driven filtration process with narrow pore size range $(<0.001 \mu \mathrm{m})$ thus almost separates out all monovalent ions or impurities thus recovers clean water (Figure 1) $[18,19]$.

Polyether Sulfone (PES) membrane due to its outstanding thermal, oxidative, hydrolytic and mechanical stability is widely used in various separation processes. PES is prepared by phase inversion method and final membrane structure depends upon solvent, concentration, additives, non-solvent, coagulation bath and temperature of PES solution [20]. PES membrane finds its major application in bio-medical field due to its biocompatibility with blood, for example in various blood related diseases such as (hemodialysis, hemofiltration, plasmapheresis etc.) where it is used in artificial organs for blood purification. Besides its advantageous properties, PES membranes being hydrophobic in nature are prone to membrane fouling [21]. Polysulfone (PSf) is one of the most commonly used polymers for membrane fabrication due to its thermal stability, $\mathrm{pH}$ resistant, mechanical strength and chemical inertness. PSf ultra-filtration (UF) membranes are used in a wide range of applications, such as hemodialysis, water treatment and protein purification etc. Membrane fouling, which is caused by the inherently hydrophobic characteristics of PSf, dramatically decreases the membrane performance and its working lifetime, thus cause its major roadblock towards membrane applications [22]. Thus, many efforts have been

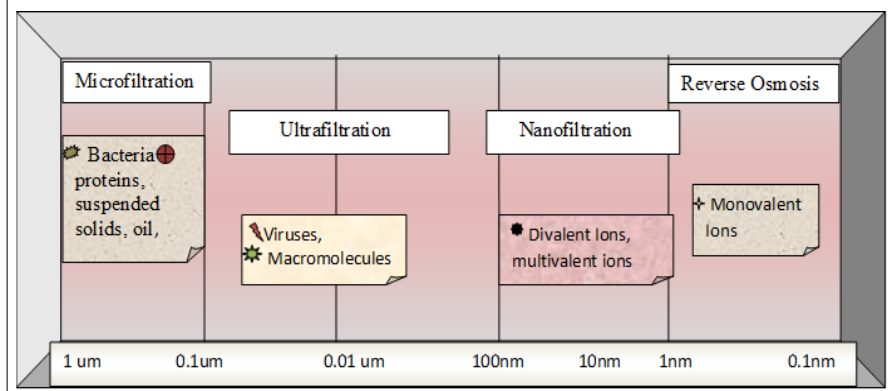

Figure 1: Filtration Spectrum for pressure driven membrane separation processes. 
devoted in improving membrane hydrophilicity and filtration properties via its modifications, such as by addition of hydrophilic Polyethylene Glycol (PEG) or Polyvinyl Pyrrolidone (PVP) in the membrane casting solution. PEG or PVP can promote the pore formation in the polymeric membranes and enhance their permeation properties [23]. Jeonghyun et al. [24] modified Polysulfone membrane (PSf) with tetrahydrofuran followed by water pressure ( 8 bars) for separation of sodium alginate. They concluded that modified PSf supports showed high water flux of $259 \mathrm{~L} / \mathrm{m}^{2}$ and $98.8 \%$ rejection of sodium alginate in sodium alginate filtration test. PVDF is another polymeric membrane used in UltraFiltration (UF), Microfiltration (MF) membrane preparation and in Membrane Bioreactors (MBR) due to its good thermal, mechanical stability and high chemical resistance [25]. Because of their hydrophobic nature, they are susceptible to fouling which limits their use in filtration process and applications in wastewater treatment, pharmaceutical industry and shortens their working life span. Fouling can be reduced by surface modification of PVDF membrane through coating hydrophilic layer of various nanoparticles on its surface via crosslinking or physical adsorption [26-28]. Nevstrueva et al. [29] prepared $\mathrm{TiO}_{2}$ blended cellulose membrane for ultra-filtration (UF) process and investigated the effect of nanoparticle size on membrane performance. They studied that $\mathrm{TiO}_{2}$ nanoparticle with size $10 \mathrm{~nm}$ provides good antifouling properties as compared to using large particle size of $26-30 \mathrm{~nm}$. Liu et al. [30] compared separation performance of PVDF membranes with fabricated PVDF/ $\gamma-\mathrm{Al}_{2} \mathrm{O}_{3}$ using $2 \mathrm{wt} \% \gamma-\mathrm{Al}_{2} \mathrm{O}_{3}$ and found better performance. Oh et al. [31] fabricated PVDF UF membrane by using $\mathrm{TiO}_{2}$ nanoparticles dispersed into casting solution using PET films and nonwoven fabric as support. Resulted nano-composite membrane showed improved fouling resistance. Cellulose Acetate (CA) membranes have been used commercially for many gas separation applications, due to their high solubility towards $\mathrm{CO}_{2}$ and Hydrogen Sulfide $\left(\mathrm{H}_{2} \mathrm{~S}\right)$ within the CA-polymer matrix [32]. Ahmad et al. [33] fabricated mixed matrix membrane from cellulose acetate modified with multi-walled carbon nanotubes and studied higher permeation ability of modified mixed matrix membrane for $\mathrm{CO}_{2} / \mathrm{N}_{2}$ gas separation. Lee et al. [34] studied the surface properties of cellulose acetate membrane modified with chitin nanocrystals through surface coating. They concluded that modified hydrophobic Cellulose Acetate (CA) mats with contact angle of $132^{\circ}$ decreased to $0^{\circ}$ after modification resulted in super-hydrophilic membrane. Rejection of humic acid, Bovine Serum Albumin (BSA) and high flux were also observed. Cellulose Triacetate (CTA) has been using as popular polymeric membrane material for preparation of ultrafiltration membranes in dialysis, reverse osmosis and Forward Osmosis (FO) since 1960s due to its good desalting properties, suitable toughness, high biocompatibility and cost effectiveness. CTA membranes also possess hydrophilic character thus plays an important role in fouling mitigation [35].

\section{Membrane Fouling}

Membrane fouling is defined as a process of deposition of macromolecules (polysaccharides, proteins), colloids, microorganisms (bacteria, viruses) and salts (multivalent/monovalent) on the surface of membrane or inside the pores of membrane. Major drawbacks of membrane fouling includes decline in permeation flux, selectivity change and reduction in membrane life during filtration operation. On the basis of nature of foulants and membrane processes fouling can be categorized into inorganic fouling, colloidal fouling, organic fouling and biofouling [36,37]. Thus, fabrication of fouling resistant membranes is a common strategy for fouling mitigation as it reduces foulants coagulation on membrane which results in clogging. Hence, it helps in decreasing demand for energy which otherwise increased due to pressure generated in consequence of fouling during membrane separation processes. These membranes are characterized on the basis of hydrophilicity, surface smoothness and its biocidal properties which avoid accumulation of foulants on membrane surface (Figure 2) [38].

\section{Types of fouling}

Inorganic fouling or mineral scaling results from the precipitation of inorganic salts crystals such as Calcium phosphate $\mathrm{Ca}_{3}\left(\mathrm{PO}_{4}\right)_{2}$, Calcium carbonate $\left(\mathrm{CaCO}_{3}\right)$, Calcium sulphate $\left(\mathrm{CaSO}_{4}\right)$ on the membrane surface due to their super saturation during filtration process. Magnesium salts are also responsible for this type of fouling. Colloidal fouling results from accumulation of inorganic/organic colloids and suspended materials on membrane surface and blockage of pores which stimulates cake formation also termed as concentration polarization. Colloidal particles consists of inorganic (oxides/hydroxides of iron, silica etc.), heavy metal hydroxides and organic colloids such as proteins and aggregated NOM. Organic fouling, on the other hand is caused by Dissolved Organic Matter (DOM) in water such as natural organic matter in the form of Soluble Microbial Products (SMP), humic substances, polysaccharides and proteins $[39,40]$. NOM has been considered as a major foulant during membrane treatment of sea water, brackish water and surface water, which results in irreversible fouling due to hydrophobic fraction of natural organic matter which results in strong adsorption to membrane surface thus decrease in permeation flux. It is mainly observed in pressure driven membrane processes such as UF, MF etc. [41-43]. Out of all of these, Biofouling is a major type of fouling results from deposition of microorganisms such as fungi, bacteria, viruses and extracellular biopolymers (Proteins, lipids, glycoproteins, lipoproteins and polysaccharides). It's a dominant type of fouling because of multiplication, growth, relocation of microorganisms on the surface of membrane. Biofouling starts due to adhesion of bacteria/ bacterium on the membrane surface followed by multiplication and growth in the presence of feed water nutrients [44,45]. Microorganisms (bacteria) first forms sessile colony on membrane surface and after sometime, sessile microbes started forming biofilm [46]. After permanent attachment, microorganisms release extracellular polymeric secretions. These extracellular polymeric secretions assist in biofilm formation due to their accumulation on membrane surface. Foulants attached to membrane surface due to interactions such as hydrogen bonding, hydrophobic and weak Van-der-Waals forces etc. [47]. Type of membrane fouling and characteristics of foulants are determined by various factors such as concentration of major constituents, membrane properties (hydrophobicity, surface morphology, charge and molecular cut off), water chemistry (ionic strength, concentration of divalent cation and $\mathrm{pH}$ ), hydrodynamic conditions such as cross flow

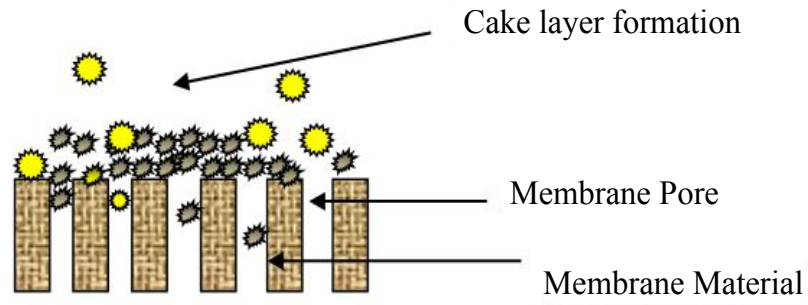

Figure 2: Blockage of membrane pores due to foulants. 
velocity, initial permeate flux and kind of operation mode. Biofouling is an irreversible phenomenon which destroys membrane surface and shortens its performance life [48].

Mitigation of fouling: Polymeric membranes being hydrophobic in nature are more susceptible to fouling. In order to mimic polymer membrane fouling, various solutions are available such as traditional methods which involves physical cleaning via backwash (A process where permeate is used in flushing membrane backwards), relaxation (prior to filtration process), chemical cleaning of membrane using acids, caustic soda and hypochlorite, changing flow mode (cross flow filtration and low flux operation) and ultrasonic entrenchment prior to installation are some of the strategies to avoid fouling [49]. Pretreatment with physical or chemical cleaning is done to control fouling but due to limitation of some polymeric membranes towards chemical cleaner, it is not an effective strategy as it may cause damage to membrane material. Another alternative method used is chemical modification of surface by addition of additives materials such as chitosan, starch, $\mathrm{FeCl}_{3}$, coagulants and powder activated carbon siloxane, hydrophilic carbonaceous materials such as graphene oxide and carbon nanotubes, incorporation of metals and metallic oxide nano materials such as $\mathrm{ZnO}$, Silica, $\mathrm{TiO}_{2}, \mathrm{Mg}(\mathrm{OH})_{2}, \mathrm{Al}_{2} \mathrm{O}_{3}, \mathrm{CaCO}_{3}$, Zeolite, Silver to form hybrid materials results in enhancement of membrane hydrophilicity, water flux, improved mechanical, selectivity, permeability, increase in salt rejection, chemical and thermal stability. Due to improvement in hydrophilicity of membrane and being cost effective, fabrication of membrane material using nano-materials is an easy and well- developed method [5054]. Another way of mitigating fouling is flow configuration and flow velocity to prevent formation of cake layer on membrane surface due to foulants aggregation. Two known flow configurations are dead end flow and cross flow. In dead end filtration flow, direction of feed side is same as that of membrane so there is a great chance of foulants to accumulate on membrane's surface to form cake layer and block the passage for water thus reducing water flux. Whereas, in cross end filtration feed flows in direction opposite (or tangentially) to feed side of membrane which results in less chance of foulants layer formation and more water flux (Figure 3) [55].

\section{Polymer Nano-composite Membranes}

Polymer nano-composite membranes are modified type of polymeric membranes with nano-materials dispersed in their matrices. Polymer nano-composite membranes find their application in organic solvent nanofiltration, pervaporation, water treatment, direct methanol fuel cells, sensor applications, gas separation and proton exchange membrane fuel cells. Besides these nano-composite membranes are widely used for liquid-solid, gas-gas, and liquid-liquid separations. Nano-fillers/nano-materials used in nano-composite membranes are classified into organic material, inorganic material, hybrid material (two or more material types) and biomaterials. Phase inversion method is used for fabrication of polymer nano-composite membranes in either hollow fiber or flat sheet configurations by dispersing nano-materials in polymer solution prior to Phase Inversion process (Figure 4) [56].

\section{Types of nano-composite membranes}

Polymer nano-composite membranes are divided into two types; Thin-film nanocomposite membranes and Blended nano-composite membranes. In blended nano-composite membrane, nano-particles along with polymer are dispersed in casting solution prior to membrane casting. Nano-composite membranes obtained in this way are known as nano-particles entrapped membranes or nano-particles blend membranes. Whereas, in thin film nano-composite membrane nano-

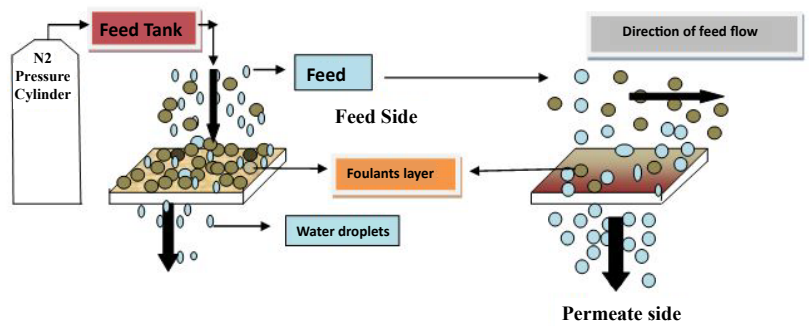

Figure 3: Diagrammatic representation of dead end and cross flow filtration process.

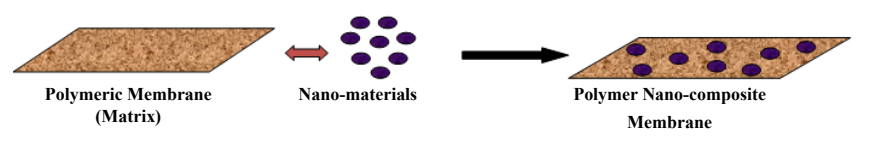

Figure 4: Represention of Polymer Nano-composite Membrane

particles form thin film on membrane surface through self-assembly by dip-coating method or deposited on prepared membrane surface with pressure [57]. Pour jafar et al. [58] prepared thin-film nano-composite membrane of Polyethersulfone (PES) with $\mathrm{TiO}_{2}$ nano-particles using additives (PVA and glutaraldehyde) by dip-coating method. They also fabricated $\mathrm{TiO}_{2}$ entrapped PES mixed matrix membrane by dissolving $\mathrm{TiO}_{2}$ in DMAc alongwith PVP additive, prepared casting solution was stirred for $24 \mathrm{~h}$ at $25^{\circ} \mathrm{C}$. Phase inversion was done in water coagulation bath where PVP leaches out during solution phase inversion, pores formed and $\mathrm{TiO}_{2}$ entrapped within membrane matrix and pores. Polymer nano-composite membranes are fabricated with nanofillers for enhancing electrical, thermal and mechanical properties of polymeric membrane. It is achieved by homogeneous dispersion of nano-fillers in polymer matrix and chemical and physical bounding with polymeric membrane. Agglomeration of nano-particles during fabrication process results due to interfacial tension and incompatibility between organic and inorganic components thus results in inappropriate dispersion. This problem can be minimize by surface treatment of nano-particles for better dispersion into polymer matrix or using dispersion agent for binding inorganic particles and organic polymers (both are immiscible) [27].

Polymer Thin Film Nano-composite (TFC) Membranes: Polymer Thin Film Nano-Composite (TFC) membranes have received greater interest in recent years in wastewater treatment and purification processes due to high thermal stability and resistance to $\mathrm{pH}$ changes. Incorporation of Nanoparticles (NP) within TFC membranes to form nano-composite TFC membrane results in enhancement of membranes physiochemical properties such as mechanical stability, permeability, selectivity, thermal resistance and hydrophilicity. Nanoparticles fabricate on thin film membrane by two methods either direct deposition on membrane surface or encapsulation within TFC membrane by interfacial polymerization. During high pressure filtration process, leakage of nano-particles is an issue which can be overcome by surface modification of nano-particles by chemical functionalization. Commonly used nano-fillers for TFC membranes are silica, zeolite, titanium dioxide, graphene oxide, silver and carbon nanotubes (Figure 5) [59-61]. 


\section{Membrane Preparation Methods}

Different preparation techniques such as dip-coating, sintering, track-etching, stretching, template leaching and phase inversion method are employed for membrane preparation with desired morphology and properties. But above all, phase inversion method is most important and common process for preparation of membranes from large number of building blocks of polymer [62-64].

\section{Phase inversion method}

Phase inversion is defined as a demixing process in which homogeneous polymer solution in liquid state is transformed into solid state (using co-agulation bath) in a controlled manner. Demixing results due to solvent exchange from polymer solution with non-solvent in coagulation bath (containing non-solvent) [65]. Phase inversion technique is used for preparation of asymmetric membrane with dense and thin skin layer. Most of the lab and commercial membranes are prepared by phase inversion method. Choice of solvent, polymer solution composition, non-solvent system, conditions of film casting and composition of coagulation bath are some key factors which influence phase inversion method for membrane formation [66]. Phase inversion method is classified into four different types: Non-Solvent Induced Phase Inversion (NIPS), Thermally Induced Phase Inversion (TIPS), Evaporation Induced Phase Inversion (EIPS) and Vapor Induced Phase Inversion (VIPS). Out of these techniques, first commercially explored and common method for membrane formation with desired morphology is immersion precipitation or Non-Solvent Induced Phase Inversion (NIPS). In Non-Solvent Induced Phase Inversion (NIPS) method, homogeneous polymer solution is prepared with suitable solvent (dope) with non-woven fabric support and cast on flat surface followed by immersion in coagulation bath containing non-solvent due to exchange of solvent and non-solvent to form polymer membrane. Morphology of polymeric membrane depends upon mutual exchange of two solvents. NIPS method is commonly employed for preparing asymmetric membrane with porous sub layer structure and dense skin layer [62]. NIPS method requires complicated control of the solvent exchange rate to obtain a desired structure and good performance by varying the dope composition, coagulation medium, quenching bath temperature, or evaporation time (Figure 6).

Among these techniques, Thermal Induced Phase Inversion (TIPS) and Non-Solvent induced phase inversion (NIPS) are commonly used techniques for membrane fabrication with desired morphology [65]. Yu et al. [55] prepared $\mathrm{SiO}_{2} / \mathrm{PVC}$ nanocomposite UF membrane via NIPS method and studied that hydrophilicity of $\mathrm{SiO}_{2} / \mathrm{PVC}$ nanocomposite in water is due to hydrogen bonding between $\mathrm{SiO}_{2} \mathrm{NPs}$ and hydroxyl group of water, which repels hydrophobic foulant protein due to enhanced hydrophilic character, higher BSA rejection, good antifouling ability and higher flux recovery (Figure 7).

\section{Thermally induced phase separation (TIPS)}

Thermally Induced Phase Separation (TIPS) method was first introduced by Castro in 1980 for preparation of polymeric membranes [67]. TIPS method is used for the preparation of microporous membranes with high porosity, narrow pore size distribution and unique morphology [68]. The principle behind TIPS method is based on heat transfer such that polymer solution is prepared at high temperature using diluent followed by cooling (decrease in temperature decreases solvent quality) to induce demixing and phase separation thus preparing porous membranes. Polymer solution is dissolved in a diluent (having low volatility and high boiling point) at a high temperature to

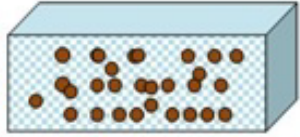

5(a)

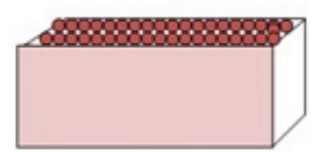

5(b)
Figure 5: (a) Blended polymer nano-composite membranes; (b) Thin film polymer nano-composite membrane.

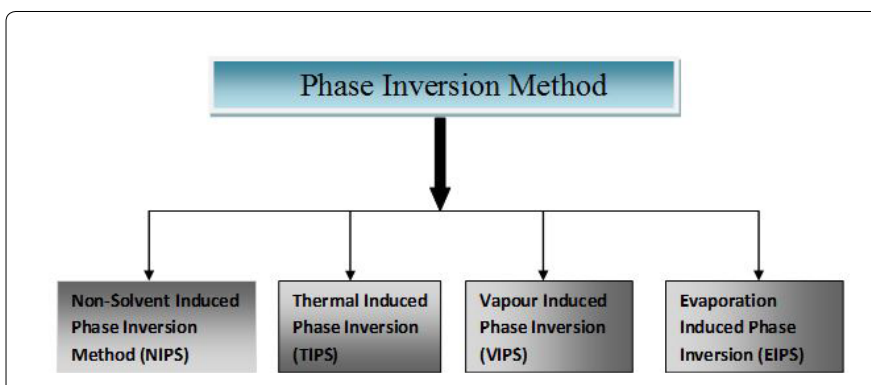

Figure 6: Schematic representation of different phase inversion methods.

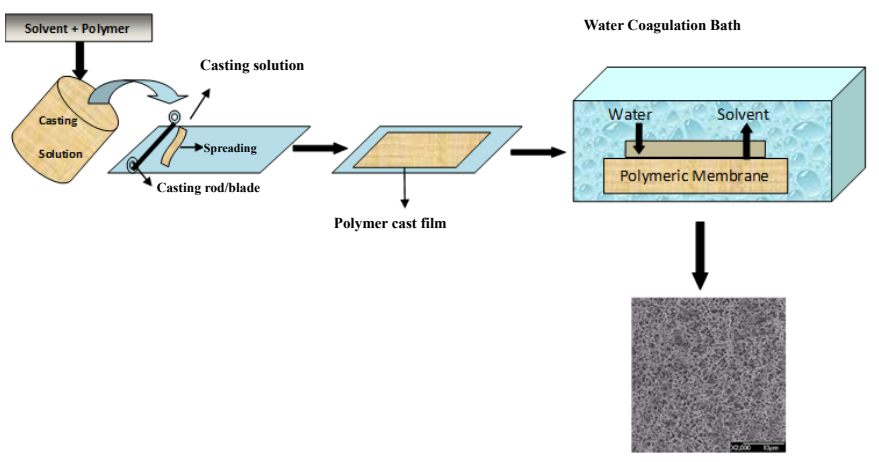

Figure 7: Steps involved in Non-Solvent Induced Phase Inversion Method (NIPS).

form homogeneous polymer solution. After phase inversion, diluent is extracted using volatile reagent thus producing porous membrane. A diluent should have high miscibility with polymer, good thermal stability and low volatility [69]. As compared to NIPS, TIPS method has several advantages, such as low tendency for defects formation, and diversity in pore structures formation (e.g. cellular, sheet-like, spherulitic, lacy, needle-like, sponge like pores). Membranes prepared via TIPS method possess higher mechanical strength, higher porosity, and more uniform porous structures than those prepared by NIPS [70,71] Various polymers such as polyethylene, polyacrylonitrile, polypropylene, poly (vinylidene fluoride), poly (methyl methacrylate) are prepared with TIPS method (Figure 8) [72,73].

Rajabzadeh et al. [74] prepared PVDF membrane blended with PMMA (Poly Methyl Methacrylate) using TIPS method and compared results with non-blended PVDF membrane. Studies showed that surface porosity became high by keeping polymer concentration (30 wt \%) fixed in dope solution, thus increasing water permeability. PVDF membrane prepared by TIPS method was found to be more significant in permeation performances, mechanical strength and pore size distribution as compared to produce by NIPS method [75]. Ding 


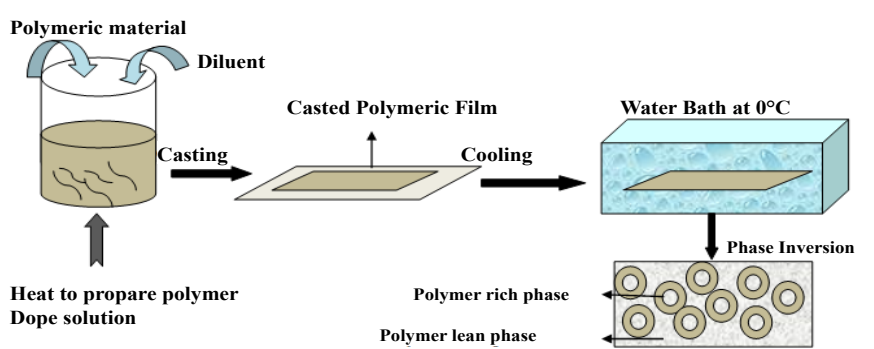

Figure 8: Steps involved in Thermal Induced Phase Separation (TIPS).

et al. [76] fabricated polyethylene membrane (ultrahigh molecular weight) with decalin and diphenyl ether as diluents via TIPS method with porous structure. Increased porosity up to $45 \%$ was obtained when polymer concentration was fixed to $10-40 \mathrm{wt} \%$.

\section{Vapor induced phase separation (VIPS) \& evaporation induced phase separation (EIPS)}

Vapor Induced Phase Separation (VIPS) is another method for preparation of highly porous membranes, e.g. microfiltration membranes. This method is based on exposure of casted film to atmosphere of non-solvent (usually water) vapors in a vapor chamber. Phase inversion takes place due to inflow of non-solvent vapors into polymeric casted film and outflow of solvent from casted film. Mass transfer of non-solvent vapors is dominated as compared to solvent due to its low volatility [77-79]. Peng et al. [72] prepared PVDF membrane via VIPS method using various exposure times. Results showed that long time exposure facilitated crystallization process leads to formation of porous membrane and increased hydrophilicity thus high water permeability. Similarly, Evaporation Induced Phase Inversion (EIPS) method involves preparation of polymer solution in a solvent or mixture of solvents (volatile in nature). Phase inversion takes place due to evaporation of solvent because of its volatility results in demixing thus forming porous structure. It is also called solution casting method (Figure 9) [80].

\section{Role of additives in membrane fabrication}

Additives also play an important role in membrane fabrication. Commonly used additives are macromolecules such as Polyethylene glycol (PEG), Polyvinyl pyrrolidone (PVP), Poly Ethylene Oxide (PEO), inorganic salts such as $\mathrm{ZnCl}_{2}$ and $\mathrm{LiCl}$ and Water. Organic compounds such as alcohols, glycerol and dialcohols. Additive can be used either as a single component or in the form of mixture [81]. Pore forming agent is used to form uniform finger like porous structure. Polyvinyl Pyrrolidine (PVP) being an excellent pore forming agent due to its hydrophilicity and solubility controls microstructure of membranes. PVP also act as an anti-biofouling agent thus prevents surface biofouling by enhancing surface hydrophilicity [82-84]. However, during phase inversion it leaches out along with organic solvent to the non-solvent phase. This problem overcomes by blending PVP grafted copolymer or by directly grafting on polymeric membrane surface [85]. Poly Ethylene Glycol (PEG) is also used as pore forming agent and imparts hydrophilic character. PEG is available in different molecular weights such as PEG 200, PEG 400, PEG 6000 and PEG 20,000 etc. [86]. Various kinds of additives and solvents used for fabrication of polymeric membranes are enlisted in Figure 10. Cross-linking agent is added to casting solution to bind polymer chemically through internal cross linking to give them toughness and insolubility [75]. Surface modifiers are added to modify hydrophilicity of membrane surface and also enhance photocatalytic, anionic, cationic and amphiphilic properties of surface. Increase in mechanical strength, chemical and thermal stability is achieved by using fillers which also prevents swelling [87].

Additives such as polyethylene glycol (PEG) and Polyvinyl Pyrrolidine (PVP) also plays their role in increasing water flux. Studies have shown that with the increase in molecular weight of PEG additive (400Da, $600 \mathrm{Da}, 2000 \mathrm{Da}, 6000 \mathrm{Da}, 12,000 \mathrm{Da}$ and 20,000 $\mathrm{Da})$ pore numbers and pore area increases which results in higher water permeability and hence higher water flux [88-95]. Similarly, Polyvinyl Pyrrolidine (PVP) shows increase in water flux with increase in its concentration as demonstrated by various studies. Increase in concentration facilitates macrovoids in membrane support layer which increases membrane surface porosity and hydrophilicity hence high water flux. PVP improves membrane hydrophilicity thus increases permeation flux. Fabrication of membranes with high PVP conc. exhibits porous structure with wider finger like macro voids and shows high permeation flux $[86,96-103]$.

\section{Modification of Polymeric Membranes}

Different methods have been developed for modification of polymeric membranes such as (a) Surface modification via surface coating and surface grafting. Surface grafting is done by different means (i.e. plasma treatment, UV irradiation etc.) (b) Bulk modification includes radical polymerization and blending of membranes with hydrophilic additives (incorporation of nanoparticles via interfacial polymerization) [104-109]. Blending with hydrophilic additives to modify membrane properties doesn't require additional step during composite membrane preparation. Different properties can be obtained

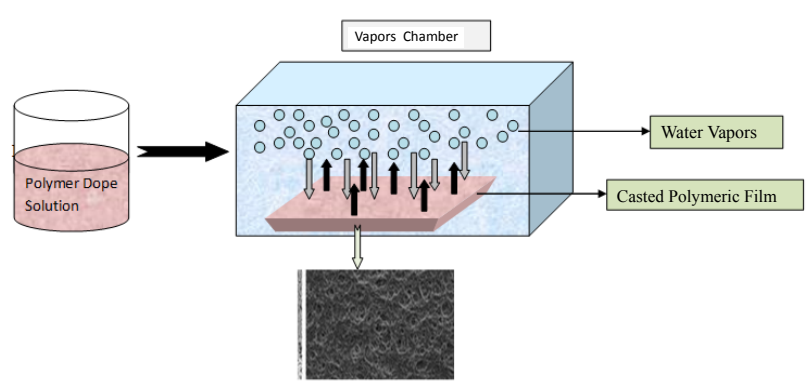

Figure 9: Schematic representation of VIPS method.

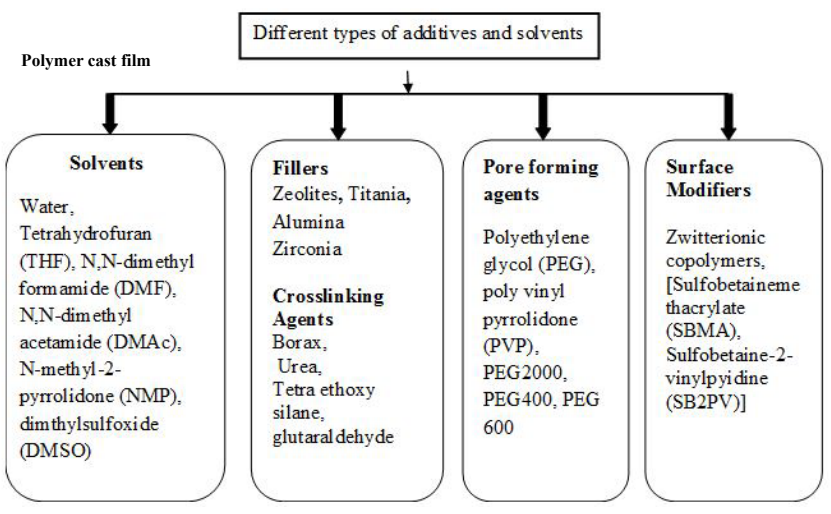

Figure10: Various additives and solvents used for fabrication of polymer nano-composite membrane 
by tailoring membrane with varying blend composition to obtain desired membrane structure. For this purpose, inorganic nano-materials are used as nanofillers to incorporate into polymer matrices for enhanced membrane performance $[82,110,111]$. Among these methods, surface grafting and surface coating are commonly used to enhance anti-fouling property and imparting hydrophilic character to membrane. But these methods only modify outer surface of membrane, not internal pores and also requires post-treatment for membrane fabrication [112]. It has been found that blending inorganic fillers with polymeric membranes enhanced their antifouling property, hydrophilicity and water flux (Figure 11) [113,114]

One of the technical problems with inorganic fillers for using as additives is their less compatibility with polymers at interface due to difference in nature results in non-uniform dispersion in membrane matrix and sometimes detaches gradually from membrane, thus deteriorates antifouling efficiency and is a major cause of secondary pollution. Modification of polymeric membrane is also attained by blending polymer with amphiphilic copolymers and homopolymers $[115,116]$. Poly Ethylene Glycol (PEG) and Polyvinyl Pyrrolide (PVP) are common hydrophilic homopolymers used as additives to improve membrane performance during membrane preparation. Extrusion of homopolymers or dissolution during filtration and membrane formation may results in deterioration of antifouling properties. In comparison to homopolymers, amphiphilic copolymers comprised of both hydrophobic and hydrophilic segments which shows their compatibility with host membrane and thus improves its hydrophilicity. It has been reported that blending membrane matrix with amphiphilic copolymers results in lower leakage as compared to homopolymers. But high costs and complex synthesis conditions results in lower production of modified membranes at large scale [117], shown in Table 1.

\section{Membrane modification with metal and metal oxides nano- materials}

Integration of antibacterial agent within polymer membrane matrix is extensively studied to inhibit microorganism's growth. Different nanoparticles or combination of nanoparticles are used to prepare nanocomposite membranes such as $\mathrm{Fe}$, Alumina $\left(\mathrm{Al}_{2} \mathrm{O}_{3}\right)$, Graphene Oxide (GO), Mesoporous Silica $\left(\mathrm{SiO}_{2}\right)$, GO-Ag, Silver (Ag), Zinc Oxide $(\mathrm{ZnO})$, Copper $(\mathrm{Cu})$, Titania $\left(\mathrm{TiO}_{2}\right)$, Zeolite, Iron Oxide $\left(\mathrm{Fe}_{2} \mathrm{O}_{3}\right)$, Zirconium $\left(\mathrm{ZrO}_{2}\right)$ with enhanced thermal, mechanical stability, high flux, salt rejection, enhanced antifouling and antibacterial properties [118-120]. Modification of polymeric membranes with various metal and metal oxides is shown in Table 2.

Silver based polymeric nano-composite membranes: Silver has been using as a common antibacterial agent due to its efficient antibacterial property, broad spectrum, low cytotoxicity and no resistance induce by them in membrane technology. They are used in antibacterial film

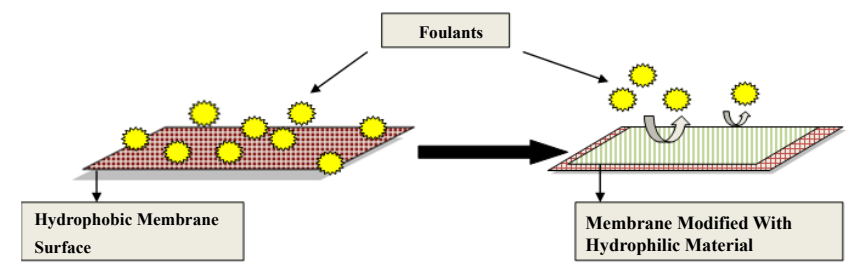

Figure 11: (a) Before modification foulants attached to hydrophobic membrane surface; (b) Repelling of foulants after modification with hydrophilic material coating on membrane surface. formation, in medical device coatings, surgical wounds dressings and in commercial products [121]. Silver has attracted a lot of attention in modification of porous membrane in last few decades. Due to its antibacterial property, anti-pollution capacity and chemical stability it is an excellent candidate for membrane surface modification [60]. The antibacterial action of silver is due to interaction of silver with sulfur containing groups especially thiol groups (which contains sulfur (S-H) and phosphorous groups present in cysteine and other compounds) of bacterial DNA. Bacterial growth is inhibited by release of ionic silver which interacts with sulfur group containing disulfide bond (S-Ag) present in bacterial protein results in destruction of bacterial growth Silver also dimerize DNA and interrupts electron transport chain due to its antiviral properties too. Besides these effective properties of silver, leaching of silver from membrane surface is one of the challenging problems because surface of membrane is the most likely location for biofouling. Antibacterial activity of AgNPs is affected by its stability and size, dispersion of bare AgNPs in aqueous environment is prone to aggregation thus decreasing in stability and antibacterial property. Leaching can reduce membrane performance with time and can pose threats to marine life and human being during drinking water obtained from wastewater treatment/desalination process [122]. In order to overcome this issue, silver is blended with other nano-particles to form nano-composites which immobilize silver nanoparticles on membrane surface and enhance its antibacterial activity. Pan et al. [122] modified PVDF membrane with Ag nanoparticles (possess antibacterial properties) and hydrophilic character of silica $\left(\mathrm{SiO}_{2}\right)$ nanoparticles using dip-coating method. Silver nanoparticles were immobilized with $\left(\mathrm{SiO}_{2}\right)$ nanoparticles on membrane surface. They studied high water permeation flux and hydrophilicity of modified PVDF ultrafiltration membrane with $\mathrm{Ag} / \mathrm{SiO}_{2}$ nano-composites. Das et al. [121] synthesized hybrid materials using Ag nanoparticles in graphene oxide suspension. Silver (Ag) was synthesized from chemical reduction of $\mathrm{AgNO}_{3}$. Resulted hybrid material showed great antimicrobial activity against gram negative bacteria such as Pseudomonous aeruginosa and Escherichia coli.

Copper based polymeric nano-composite membranes: Copper shows excellent antibacterial properties and is superior as compared to other nano-particles due to its easy availability and low cost. High antimicrobial activity of copper ions, their oxides and metals/alloys has been demonstrated in various studies [123]. Antibacterial activity of copper is due to immobilization of $\mathrm{Cu}-\mathrm{NPs}$ with the help of in situ formation method thus results in great fouling control [124]. Chen et al. [125] fabricated hybrid PES membrane via phase inversion method using copper ions and halloysite nanotubes as nanofillers, resulted in nanohybrid membrane with efficient biofouling control. Zhang et al. [126] modified thin-film composite (TFC) membrane with copper nano-particles which showed high antibacterial and antifouling properties due to antibacterial activity of copper nano-particles and low flux reduction after fouling thus results in long lasting membrane life.

Titanium dioxide $\left(\mathrm{TiO}_{2}\right)$ based polymeric nano-composite membranes: Titanium dioxide nanomaterial $\left(\mathrm{TiO}_{2}\right)$ emerged as an outstanding material for the fabrication of nano-composites membranes due to their photo catalytic and hydrophilic nature for the degradation of organic pollutants in waste water treatment. $\mathrm{TiO}_{2}$ nanomaterial is widely used in membrane fabrication due to its antifouling ability, hydrophilic character and high stability. Photocatalytic activity of $\mathrm{TiO}_{2}$ is limited to UV region due to its large band gap about $3.2 \mathrm{eV}$ and cannot absorb visible light $[127,128]$. Kuvarega et al. [129] prepared N,Pd codoped $\mathrm{TiO}_{2}$ polysulfone membranes via phase inversion method for photocatalytic degradation of dye. Their results revealed that Anatase 
Citation: Zahid M, Rashid A, Akram S, Rehan ZA, Razzaq W (2018) A Comprehensive Review on Polymeric Nano-Composite Membranes for Water Treatment. J Membr Sci Technol 8: 179. doi:10.4172/2155-9589.1000179

Page 8 of 20

\begin{tabular}{|c|c|c|c|c|}
\hline Sr. No. & Membrane Material & Modification Method Membrane Surface Modification & Application & References \\
\hline 1 & Polyether Sulfone (PES) & Grafting with D-tyrosine and pre-coating with polydopamine (PDA) & Wastewater treatment & [174] \\
\hline 2 & PES & $\begin{array}{l}\text { Crosslinking of PES membrane with glutaraldehyde and coating with N, O-carboxy methyl } \\
\text { chitosan (NOCC). }\end{array}$ & $\begin{array}{l}\text { Separation of nickel ions } \\
\text { from aqueous solutions }\end{array}$ & [175] \\
\hline 3 & PES & $\begin{array}{l}\text { Coating of PES membrane with PVA and immersion into cross-linking bath with } 0.5 \% \\
\mathrm{H}_{2} \mathrm{SO}_{4} \text { and glutaraldehyde (5wt \%) }\end{array}$ & I & [176] \\
\hline 4 & $\begin{array}{l}\text { Polytetrafluoroethylene } \\
\text { (PTFE) membrane }\end{array}$ & Coating with polymerized dopamine (PDA) and poly (ethyleneimine) (PEI) & Wastewater treatment & [177] \\
\hline 5 & $\begin{array}{l}\text { Polyvinylidene } \\
\text { fluoride(PVDF) }\end{array}$ & $\begin{array}{l}\text { Grafting of PVDF membrane with hydrophilic hydroxyethyl acetate (HEA) via radiation } \\
\text { grafting. }\end{array}$ & I & [178] \\
\hline 6 & $\begin{array}{l}\text { Polysulfone membrane } \\
\text { (PSF) }\end{array}$ & $\begin{array}{l}\text { Cross-linked polymerization of PSF with copolymer monomers vinyltriethoxysilne } \\
\text { (VTEOS) and acrylic acid (AAA) and casting by NIPS }\end{array}$ & $\begin{array}{l}\text { Water purification and water } \\
\text { separation }\end{array}$ & [179] \\
\hline 7 & PSF & $\begin{array}{l}\text { Coating of PSF UF membrane with zwitterion Poly (2-methacryloxyethyl } \\
\text { phosphorylcholine) (PMPC) incorporated with polydopamine }\end{array}$ & Oil-water separations & [180] \\
\hline 8 & PSF & $\begin{array}{l}\text { Grafting with zwitter ionic polymers carboxybetaine methacrylate(CBMA) via atomic } \\
\text { transfer radical polymerization }\end{array}$ & Industrial applications & [181] \\
\hline 9 & RO membrane & $\begin{array}{l}\text { Coating of amphiphilic copolymer film on RO membrane with hydrophilic hydroxyethyl } \\
\text { methacrylate (HEMA) and hydrophobic perfluorodecylacrylate (PFA) monomers }\end{array}$ & Wastewater treatment & [182] \\
\hline 10 & $\begin{array}{l}\text { Polyamide RO } \\
\text { membrane }\end{array}$ & $\begin{array}{l}\text { Polymerization grafting enhanced with polarization using surfactant (Triton X-100) and } \\
\text { hydrophobic monomer glycidyl methacrylate }\end{array}$ & Boron rejection & [183] \\
\hline 11 & $\begin{array}{l}\text { Polyamide RO } \\
\text { membrane (TFC) }\end{array}$ & $\begin{array}{l}\text { Coating with poly acrylic acid and antimicrobial agent (tobramycin) using assembly layer } \\
\text { by layer technique. }\end{array}$ & $\begin{array}{l}\text { Application in wastewater } \\
\text { for killing of Gram negative } \\
\text { bacterium (Escherchia coli) } \\
\text { and Gram Positive Bacillus } \\
\text { subtilis }\end{array}$ & [184] \\
\hline 12 & $\begin{array}{l}\text { Polyethylene membrane } \\
\text { (PE) }\end{array}$ & Ozone treatment of PE membrane followed by grafting with poly (ethylene imine) (PEI). & $\begin{array}{l}\text { Water emediation from } \\
\text { leaching of biocidal silver }\end{array}$ & {$[76]$} \\
\hline 13 & $\begin{array}{l}\text { MF, UF, NF and RO } \\
\text { membranes }\end{array}$ & $\begin{array}{l}\text { Modification of surface with polydopamine and grafting with fouling resistant Polyethylene } \\
\text { glycol(PEG) }\end{array}$ & Water purification & [185] \\
\hline 14 & $\begin{array}{l}\text { Polysulfone UF } \\
\text { membrane }\end{array}$ & $\begin{array}{l}\text { Modification of PSf membrane with surface zwitterionicalization using PSF-based block } \\
\text { copolymers such as poly (N,N-dimethylamino-2-ethylmethcrylate) (PDMAEMA) }\end{array}$ & $\begin{array}{l}\text { Blood filtration and protein } \\
\text { separation }\end{array}$ & [186] \\
\hline \multicolumn{5}{|c|}{ Modification by Blending } \\
\hline 15 & PES & $\begin{array}{l}\text { Casting of PES membrane with iron-tannin- framework (ITF) complex as additive (0.9wt. } \\
\%) \text {. }\end{array}$ & Wastewater treatment & [187] \\
\hline 16 & $\begin{array}{l}\text { Polyvinylidene } \\
\text { fluoride(PVDF) }\end{array}$ & $\begin{array}{l}\text { Casting of PVDF membrane with carbon nanosphere }(400 \mathrm{mg} / \mathrm{L}) \text { sol as coagulation bath } \\
\text { during phase inversion }\end{array}$ & Water/wastewater treatment & [188] \\
\hline 17 & PVDF & $\begin{array}{l}\text { Blending of PVDF membrane with zwitter ionic co-polymers, sulfobetaine-2-vinylpyridine } \\
\text { (SB2VP) and sulfobetaine methacrylate (SBMA). }\end{array}$ & $\begin{array}{l}\text { Wastewater treatment and } \\
\text { oil-water separation }\end{array}$ & [189] \\
\hline 18 & Polyvinylchloride (PVC) & $\begin{array}{l}\text { Modification of PVC with pore forming agent PEG using Water/DMAc as non-solvent/ } \\
\text { solvent system }\end{array}$ & $\begin{array}{l}\text { Ultrafiltration operation of } \\
\text { waste water }\end{array}$ & [190] \\
\hline 19 & PVDF/PES & PVA blended in different concentration & Wastewater treatment & [191] \\
\hline 20 & $\begin{array}{l}\mathrm{PVC} / \text { polyvinyl formal } \\
\text { (PVF) }\end{array}$ & PVC and PVF dissolved in DMAc in different concentrations & I & [192] \\
\hline 21 & PVDF & PVDF/CA blended in different rations & I & [193] \\
\hline 22 & PES UF membrane & Blended with $1 \%$ wt PVP additive & Wastewater Reclamation & [194] \\
\hline 23 & PAN/ Chitosan & $\begin{array}{l}\text { Polyacrylonitrile (PAN) coated with chitosan biopolymers ( } 2 \text { wt \%) by dip-coating and } \\
\text { cross linked by Tri-sodium polyphosphate }\end{array}$ & Water Treatment & [195] \\
\hline 24 & $\begin{array}{l}\text { PEG/ PBMA /PHFBM } \\
\text { in PVDF; PEGMA = } \\
\text { Poly(poly(ethylene } \\
\text { glycol)-methyl ether } \\
\text { methacrylate) PBMA = } \\
\text { Poly(butyl methacrylate) }\end{array}$ & $\begin{array}{l}\text { Added AIBN as initiator and corresponding monomer and obtained amphiphilic block co- } \\
\text { polymer }\end{array}$ & $\begin{array}{l}\text { Oil-Water emulsion } \\
\text { separation }\end{array}$ & [196] \\
\hline 25 & $\begin{array}{l}\text { Polyamide (PA) } \\
\text { Membrane }\end{array}$ & $\begin{array}{l}\text { Blending of PA membrane with polyethylene glycol-functionalized polyhedral oligomeric } \\
\text { silsesquioxane (PEG-POSS) via interfacial polymerization }\end{array}$ & Nanofiltration Operation & [197] \\
\hline \multicolumn{5}{|c|}{ Reactive Modification of Membrane } \\
\hline 26 & PES & $\begin{array}{l}\text { Grafting of PES UF membrane surface with zwitterionic polymers derived from reactive } \\
\text { copolymer additive (amphiphilic in nature) }\end{array}$ & $\begin{array}{l}\text { Protein filtration, oil/water } \\
\text { separation }\end{array}$ & [75] \\
\hline 27 & Acetalized PVA & $\begin{array}{l}\text { Acetaldehyde reacting with conc. aqueous PVA solution in the presence of } \mathrm{HCL} \text {, different } \\
\text { degrees of PEG600/PVA casting solution is prepared in DMAc }\end{array}$ & $\begin{array}{l}\text { Water Treatment and } \\
\text { Protection }\end{array}$ & [198] \\
\hline 28 & Aminated PVC & $\begin{array}{l}\text { Triethylene tetramine (TETA) used for amination of PVC; and zwitterionicalized by sodium } \\
\text { chloroacetate }\end{array}$ & Waste Water Treatment & [199] \\
\hline 29 & PVDF & Reactive functionalization of PVDF membrane with amine solution & I & [200] \\
\hline \multicolumn{5}{|c|}{ Modification by Sol-Gel Method } \\
\hline 30 & PES & $\begin{array}{l}\text { PES membrane casted from N-methyl-pyrrolidine (NMP) solution and coating with } \\
\text { tetraethyl-orthosilicte (TEOS) silica precursors by sol-gel process and and dispersed in } \\
\text { ethanol in the presence of catalytic } \mathrm{NH}_{3} / \mathrm{H}_{2} \mathrm{O} \text { mixture. }\end{array}$ & $\begin{array}{l}\text { Food processing and } \\
\text { wastewater treatment }\end{array}$ & [201] \\
\hline
\end{tabular}


Citation: Zahid M, Rashid A, Akram S, Rehan ZA, Razzaq W (2018) A Comprehensive Review on Polymeric Nano-Composite Membranes for Water Treatment. J Membr Sci Technol 8: 179. doi:10.4172/2155-9589.1000179

Page 9 of 20

\begin{tabular}{|l|l|l|l|l|}
\hline 31 & PVDF & $\begin{array}{l}\text { DI water and Tetraethoxysilane (TEOS) added in DMF to yield } \mathrm{SiO}_{2} \text { with } \mathrm{HCL} \text { (for adjusting } \\
\text { pH). Sol with different concentrations doped into PVDF-DMAc solution. }\end{array}$ & Wastewater treatment \\
\hline 32 & PVC & $\begin{array}{l}\text { Glycerol, PVC and TEOS dissolved in DMAc, 50\% ethanol solution used for casting of } \\
\text { hollow fibers and tap water used as external coagulation bath. }\end{array}$ & Waterwater treatment \\
\hline 33 & PS & $\begin{array}{l}\mathrm{TiO}_{2} \text { sol is yielded by adding appropriate amount of DI water, Tetrabytyltitanate (TBT) into } \\
\text { NMP solvent- PVDF-DMAc solution for sol doped in different concentrations }\end{array}$ & Wastewater treatment \\
\hline 34 & PVDF & $\begin{array}{l}\text { PVP, LiCL, PVDF and TEOS mixture is dissolved in DMAc, acid- water bath is used for } \\
\text { casting }(\mathrm{pH}=1) \text { of mixture and TEOS gelation. }\end{array}$ & Industrial separation \\
\hline [205]
\end{tabular}

Table 1: Modification of polymeric membranes with different strategies.

\begin{tabular}{|c|c|c|c|c|c|}
\hline Sr. No. & Material & Method & Solutes Rejected & Characterization & References \\
\hline 1 & $\begin{array}{l}\mathrm{TiO}_{2} \text { Polyethersulfone } \\
\text { (PES) }\end{array}$ & Sol-gel method & 2,4-Dichlorophenol & FTIR, XRD,SEM & [127] \\
\hline 2 & $\mathrm{TiO}_{2} /$ Polysulfone (PS) & Blending & Eosin Yellow Dye & $\begin{array}{l}\text { FTIR, SEM, EDS, XRD, AFM, SAXS, Raman } \\
\text { Spectroscopy, Contact angle, Zeta Potential }\end{array}$ & [129] \\
\hline 3 & $\begin{array}{l}\mathrm{TiO}_{2} / \text { Cellulose Acetate } \\
\text { (CA)/ PVP }\end{array}$ & Dip-coating & BSA & $\begin{array}{l}\text { TGA, FESEM, contact angle, viscosity, pore size } \\
\text { distribution, SEM,FTIR, goniometer, contact angle }\end{array}$ & [206] \\
\hline 4 & $\mathrm{TiO}_{2} / \mathrm{PSF} / \mathrm{HMO}$ & Blending & Oil & -- & [207] \\
\hline 5 & $\mathrm{TiO}_{2} / \mathrm{PES}$ & Phase inversion & Free active Chlorine & $\begin{array}{c}\text { Contact angle, AFM, FT-IR, TGA, pore size } \\
\text { distribution, XPS, SEM }\end{array}$ & [208] \\
\hline 6 & $\mathrm{ZrO}_{2} \mathrm{PVDF}$ & Blending & BSA/Oil & SEM,TEM, AFM, XPS, TGA, contact angle & [209] \\
\hline 7 & PES & Blending & Ovalbumin and BSA & SEM, contact angle, Porosity & [210] \\
\hline 8 & ZnO PVC & Blending & BSA & FTIR,SEM,TG-DTA,AFM, TOC, pure water flux & [211] \\
\hline 9 & $\begin{array}{l}\text { Cellulose acetate- } \\
\text { polyurethane (CA-PU) }\end{array}$ & Blending & $\begin{array}{l}\text { Dyes (Reactive red (RR11), } \\
\text { Reactive Orange (RO 84) }\end{array}$ & $\begin{array}{l}\text { SEM, AFM, FTIR, XRD, DSC, contact angle, tensile } \\
\text { strength, viscosity }\end{array}$ & [212] \\
\hline 10 & PVDF & Blending & $\begin{array}{l}\text { BSA, humic acid, sodium } \\
\text { alginate BSA }\end{array}$ & SEM,FTIR,XRD, contact angle, zeta potential & $\begin{array}{l}{[130,132} \\
213]\end{array}$ \\
\hline 11 & PES & Blending & & SEM, AFM, XPS, Tensile strength & [214] \\
\hline 12 & $\begin{array}{l}\mathrm{Al}_{2} \mathrm{O}_{3} \mathrm{PES} \text { UF } \\
\text { membrane }\end{array}$ & Vapour induced hydrolyzation & Humic Acid (HA) & SEM, TEM, AFM, FTIR, MWCO Contact angle & [215] \\
\hline 13 & PVDF & Blending & BSA, Oily waste water & $\begin{array}{c}\text { TEM, FTIR, AFM, TGA, pore size distribution, contact } \\
\text { angle }\end{array}$ & [216] \\
\hline 14 & $\begin{array}{l}\text { Salicylate-alumoxane } \\
\text { (SA) PS }\end{array}$ & Blending & BSA & SEM, FTIR, XRD, TGA, Contact angle, Viscosity & [217] \\
\hline 15 & $\mathrm{SiO}_{2} \mathrm{PVDF}$ & Sol-gel & BSA & SEM, FTIR, Contact angle, Tensile strength & [202] \\
\hline 16 & Polysulfone (PS)/PVA & Blending & $\mathrm{Na}_{2} \mathrm{SO}_{4}$ & SEM, FTIR, Contact angle & [218] \\
\hline 17 & Polyvinylchloride (PVC) & Sol-gel & BSA & SEM, FTIR, DSC, TGA & [203] \\
\hline 18 & $\begin{array}{l}\text { PSF laminated with } \\
\text { polyamide (PA) }\end{array}$ & Dip-coating & $\mathrm{NaCl}$, dioxane, isopropanol & FESEM, FTIR, XRD,BET, TGA, zeta potential & [219] \\
\hline 19 & $\begin{array}{l}\text { Mesoporous silica/PSF } \\
\text { coated with polyaniline }\end{array}$ & Blending & Metal ions & $\begin{array}{l}\text { TEM, SEM, AFM, XRD, FTIR, contact angle, pore size } \\
\text { distribution, porosity } \\
\text { strength, SEM }\end{array}$ & [220] \\
\hline 20 & $\mathrm{Fe}_{2} \mathrm{O}_{3} \mathrm{PES}$ & Blending & Copper ion removal & SEM, FTIR, TGA, MWCO, contact angle & [221] \\
\hline 21 & $\mathrm{PVC} / \mathrm{CA} / \mathrm{Fe}_{3} \mathrm{O}_{4}$ & Blending & Lead ion & Tensile strength, SEM & [222] \\
\hline 22 & $\mathrm{CA} / \mathrm{Ti}^{-\mathrm{SiO}_{4}} \mathrm{NPs}$ & Blending & $\begin{array}{l}\text { BSA, trypsin, pepsin, egg } \\
\text { albumin }\end{array}$ & FTIR, SEM, TGA, MWCO, contact angle & [223] \\
\hline 23 & $\mathrm{PSF} / \mathrm{Fe}_{3} \mathrm{O}_{4}$ & $\begin{array}{l}\text { Blending, Interfacial } \\
\text { polymerization with polyamide } \\
\text { and } \mathrm{Fe}_{3} \mathrm{O}_{4} \mathrm{NPs} \text { and surface } \\
\text { deposition with acrylic acid }\end{array}$ & Dye & AFM, SEM, FTIR, XRD, DLS, contact angle & [210] \\
\hline 24 & $\begin{array}{c}\text { Silver (Ag) PVDF grafted } \\
\text { with PAA }\end{array}$ & $\begin{array}{l}\text { Surface adsorption and } \\
\text { reduction with silver ion }\end{array}$ & BSA & SEM, FTIR, XPS, contact angle & [224] \\
\hline 25 & PES TFC grafted with PA & $\begin{array}{l}\text { Polymerization of Ag NPs on } \\
\text { PES substrate by dissolving } \\
\text { m-phenylene diamine aqueous } \\
\text { phase into organic phase }\end{array}$ & $\mathrm{MgSO}_{4}$ & AFM, SEM, XPS & [225] \\
\hline
\end{tabular}

Table 2: Metal and metal oxides based polymer nano-composites.

type N,Pd co-doped $\mathrm{TiO}_{2}$ nanoparticles polysulfone membranes have high porosity, greater hydrophilicity, better absorption of visible light and high wetability. $0.5 \% \mathrm{wt}$ concentration of nanoparticles resulted in $66^{\circ}$ decrease in contact angle. They studied that photo degradation of dye occurred due to activation of doped nanoparticles through visible light and more than $90 \%$ dye was removed from waste water.
$\mathrm{ZnO} / \mathrm{ZrO}_{2}$ based polymeric nano-composite membranes: Due to anti-corrosive, anti-microbial, anti-fungal properties, $\mathrm{ZnO}$ nanoparticles are gaining appreciation in various industrial and biomedical fields, electronics, optics and in membrane technology. Various studies have reported incorporation of $\mathrm{ZnO}$ in various polymer matrices such as Polyethersulfone (PES), Polysulfone (PSF) and Polyvinylidine Fluoride (PVDF) to form polymer nanocomposites with enhanced 
rejection capability, hydrophilicity, porosity, high permeability and enhanced antifouling properties. It is also used in the synthesis of Ultrafiltration (UF) membrane with improved properties. It has been reported that $\mathrm{ZnO}$ nanoparticles are good candidates for better membrane quality. Zinc oxide is also used as common nanofiller in the fabrication of polymer nano-composite membranes to impart hydrophilicity and improved antifouling property. Like $\mathrm{SiO}_{2}, \mathrm{TiO}_{2}$ and $\mathrm{Al}_{2} \mathrm{O}_{3}, \mathrm{ZnO}$ is also used for membrane modification. Modification of polymeric membrane such as Polyether Sulfone (PES) membranes with $\mathrm{ZnO}$ and addition of pore forming agent PEG400 results in polymer nanocomposite membrane with enhanced water flux, antifouling property, porosity, hydrophilicity and greater flux recovery [130]. There are various mechanisms involved in inhibiting bacterial activity such as attack on bacterial cell wall/membrane, inhibits nucleic acid or protein synthesis [131]. $\mathrm{ZnO}$ nano-composite membranes possess excellent potential properties like essential heavy metal ion adsorption e.g. $\left(\mathrm{Cu}^{2+}\right)$, photocatalysis, self-cleaning, improved dye rejection ability, reduced oleic acid fouling and collagen separation [117].

Zhao et al. [130] observed the effect of $\mathrm{ZnO}$ nanoparticles on PES membrane and found $110-220 \%$ increase in water permeation thus higher flux. Liang et al. [132] fabricated PVDF membrane internal surface with $\mathrm{ZnO}$ nanoparticles, $\mathrm{ZnO}$ was added $27 \%$ of polymer weight. Due to internal hydrophilicity, $100 \%$ recovery was observed in initial fluxes during multi-cycle filtration as compared to only $78 \%$ recovery with bare membrane and twice increase in water flux was also observed. Pintile et al. [133] prepared PSf/ZnO based composite membrane with enhanced hydrophilicity, water flux, porosity and retention time. It has been found that decreasing $\mathrm{ZnO}$ nanoparticles size resulted in increased Polysulfone (PSf) membrane performance. Zirconium dioxide is well known semiconductor possessing band gap $(5.0 \mathrm{eV})$ for used as heterogenous catalyst where valence and conductance band of $\mathrm{ZrO}_{2}$ lies at $-1.0 \mathrm{eV}$ and $+4.0 \mathrm{eV}$ thus assist in its photocatalytic activity [134]. $\mathrm{ZrO}_{2}$ used as common inorganic nanofiller in membrane fabrication due to its hydrophilic nature, high physical, thermal and chemical stability [135]. Zakeritabar et al. [134] fabricated PSf membrane incorporated with zirconium dioxide $\left(\mathrm{ZrO}_{2}\right)$ and tin dioxide $\left(\mathrm{SnO}_{2}\right)$ via sol-gel method which showed enhanced water flux, good hydrophilicity, high photocatalytic activity and improved antifouling behavior. Li et al. [136] coated cellulose acetate with $\mathrm{ZrO}_{2}$ modified with alumina template for fabrication of enantioselective membrane for separating chiral enantiomers of madelic acid. Best performance was obtained with addition of $15 \%$ cellulose acetate in casting solution along with increased flux, permselectivity and high separation factor (35) as compared to traditional membrane.

Mesoporous silica and microporous zeolite nanoparticles based nano-composite membranes: Mesoporous silica and microporous zeolite nanomaterials have recieved considerable attention due to incorporation within mixed matrix membranes due to their porous structure which provides high surface area and porosity to membrane for water molecules to pass through thus improving permeability of membrane. Zeolites because of their small pore size show excellent molecular sieving properties thus used in hydrogen purification and natural gas sweetening [137]. However, they have limitation due to oriented pores and irregular cubic structure results in less dispersion into thin layer. As compared to zeolite nanoparticles, mesoporous silica nanoparticles possess regular spherical morphology, nonoriented pore distribution, uniformity, hydrophilic nature, high surface area, mechanical and thermal stability results in their high dispersion in thin film layer of membrane. These properties make them widely used in various membrane separation processes such as ultrafiltration, desalination and gas separation [138]. Because of low density, flexible porosity, biocompatibility, high surface area, mesoporous $\mathrm{SiO}_{2}$ nanoparticles has attracted considerable attention in various applications such as drug delivery, drug storage, biomolecule separations and high-performance catalysis $[71,139]$.

\section{Carbon based polymeric nano-composite membranes}

Carbon based antibacterial agents possess unique structural and electronic properties such as carbon nanotubes (single walled CNTs and multi-walled CNTs), hollow carbon sphere, graphene oxide and mesoporous carbon etc. carbon nanotubes are 1D carbon based nanomaterials derived from carbon and are known for their excellent mechanical, chemical, thermal and surface adsorption properties. They are either single walled carbon nanotubes (CNTs) or multiwalled carbon nanotubes (CNTs) possessing hexagonal carbon lattice well known for modification of membrane materials due to their low production cost, high purity and easy scaling up characteristics [140]. Wenyan et al. [141] reported the fabrication of carbon nanotube (CNT) - Polyvinyl Alcohol (PVA) composite polysulfone Ultrafiltration (UF) membrane for chromium ion removal. Increase in surface charge density of membrane surface results in increased chromium ion removal. Chan et al. [142] studied modification of polyamide membrane with zwitterion functionalized carbon nanotubes. The resulting membrane showed greater resistance to fouling, high salt rejection, high water flux and mechanical stability due to enhanced chemical crosslinking of membrane. These carbon based nano-materials because of their antibacterial activity destroys bacterial integrity by breaking bacterial cell membrane and proliferation due to superoxide anion formation. Due to good interfacial compatibility with polymeric materials these materials form nanocomposite membranes with high water flux, showed better antifouling performance and high salt rejection properties. As antibacterial agents, these materials find application in water treatment, purification and desalination [143-146]. Yasin et al. [58] fabricated mesoprous carbon nano-composite polyethersulfone membranes and observed high antibacterial ability and protein rejection when these membranes have $0.20 \mathrm{wt} \%$ concentration of MCNs. Enhanced water flux, hyrophilicity and increased antibacterial activity of mesoprous carbon PES nano-composite membrane was also observed. Tiraferri et al. [147] synthesized polyamide (PA) single walled carbon nanotubes and they observed good antibacterial activity and 60\% decrease in bacterial attachment. Yun et al. [148] studied Polysulfone (PS) membrane blended with oxidized MWCNTs as a result of increase in hydrophilicity, BSA rejection and water flux enhancement from $60 \%$ to $100 \%$. Modification of polymeric membranes with carbon based nanomaterials is shown in Table 3.

Role of graphene oxide in polymer nano-composite membranes: Graphene derivatives have gained a lot of attention as a new class of membrane material in wastewater treatment due to its outstanding chemical stability, physical properties and unique two-dimensional structure. Graphene Oxide (GO) is $\mathrm{sp}^{2}$ hybridized oxidized derivative of graphene. Oxidation of graphene results in functionalization of $\mathrm{GO}$ with oxygen containing groups such as carbonyl, hydroxyl, carboxylic group and epoxy group. Due to presence of oxygen functional groups at edges and basal plane, graphene oxide possesses amphiphilic character. These functional groups impart hydrophilicity to GO especially their sheets which due to their superior chemical stability, strong hydrophilicity and high surface area are highly feasible for use as nanofillers (additive) for polymeric membranes to form polymeric nano-composite membranes $[149,150]$. Due to its planar and 1-atom thick layer structure, graphene oxide is cost effective and exhibits excellent properties such as high 


\begin{tabular}{|c|c|c|c|c|c|}
\hline Sr No & Membrane Material & Carbon Based Nanomaterials / Method & Solute Rejection & Characterization Techniques & References \\
\hline 26 & RO membranes & Carboxylated (MWCNTs)/blending & Salt/BSA rejection & SEM,FT-IR,TEM,Contact angle & [226] \\
\hline 27 & $\begin{array}{l}\text { Polyvinylidene fluoride } \\
\text { (PVDF) }\end{array}$ & Ag-GO /Blending & Escherchia coli rejection & AFM,FT-IR,contact angle,SEM, & [227] \\
\hline 28 & TFN membrane & $\begin{array}{l}\text { Sulfonated (MWCNT) / interfacial } \\
\text { polymerization }\end{array}$ & $\mathrm{Na}_{2} \mathrm{SO}_{4}, \mathrm{MgSO}_{4}, \mathrm{MgCl}_{2}, \mathrm{NaCl}$ & $\begin{array}{l}\text { XPS,TGA,TEM,FESEM,contact angle,zeta } \\
\text { potential, } \mathrm{N}_{2} \text { adsorption desorption } \\
\text { measurement }\end{array}$ & [228] \\
\hline 29 & FO membrane & Reduced GO with polydopamine/coating & Salt rejection & XPS, XRD, SEM, FTIR, contact angle & [229] \\
\hline 30 & PVDF & Quaternary ammonium compound carbon & - & $\begin{array}{l}\text { Contact angle, AFM, gravimetric method, XPS, } \\
\text { zeta potential, EDX, SEM }\end{array}$ & [230] \\
\hline 31 & $\begin{array}{l}\text { Mixed matrix } \\
\text { membranes }\end{array}$ & $\begin{array}{l}\text { Carboxyl MWCNTs with polyimide/cross- } \\
\text { linking }\end{array}$ & Rose Bengal Dye & $\begin{array}{l}\text { FESEM, FTIR, AFM, contact angle, pore } \\
\text { size distribution, gravimetric method, mean } \\
\text { effective pore diameter. }\end{array}$ & [231] \\
\hline 32 & Polymeric membranes & CNTs with iron oxide/dopping & Sodium Alginate & $\begin{array}{l}\text { SEM, XRD, TGA, density, pore size } \\
\text { distribution, contact angle measurement }\end{array}$ & [232] \\
\hline 33 & PSf & GO/Blending & BSA & $\begin{array}{l}\text { TEM, NMR, FT-IR, TGA, XRD, FE-SEM, AFM, } \\
\text { viscosity, pore size distribution, ,contact angle, } \\
\text { zeta potential, mechanical strength }\end{array}$ & [233] \\
\hline 34 & PVDF & GO-Ag/ blending & NOM, BSA & $\begin{array}{l}\text { TEM,UV-Vis, FTIR, contct angle, tensile } \\
\text { strength, MWCO }\end{array}$ & [234] \\
\hline 35 & PA & $\begin{array}{l}\text { Reduce graphene- } \mathrm{NH}_{2} / \text { interfacial } \\
\text { polymerization }\end{array}$ & $\mathrm{NaCl}, \mathrm{Na}_{2} \mathrm{SO}_{4}, \mathrm{MgSO}_{4}, \mathrm{CaCl}_{2}$ & $\begin{array}{l}\text { SEM, FTIR, XPS, AFM, zeta potential, contact } \\
\text { angle }\end{array}$ & [235] \\
\hline 36 & PES & MWCNTs with ZnO/Blending & Direct red 16 dye & AFM, SEM, XRD, contact angle & [236] \\
\hline 37 & $\begin{array}{l}\text { Chitosan modified with } \\
\text { Zirconium (Zr-CTS) }\end{array}$ & GO/blending & Fluoride ion removal & ATR-FTIR, XPS & [237] \\
\hline 38 & PSF & Polyamine functionalized GO/ Blending & BSA & $\begin{array}{l}\text { SEM, AFM, EDX, XRD,FTIR, contact angle, } \\
\text { tensile strength, pore size distribution }\end{array}$ & [238] \\
\hline 39 & PSf & MWCNTs / Ag & $\mathrm{NaCl}, \mathrm{Na}_{2} \mathrm{SO}_{4}$ & $\begin{array}{l}\text { FTIR, TEM, SEM, AFM, Contact Angle, XRD, } \\
\text { XPS }\end{array}$ & [239] \\
\hline 40 & PES & MWCNTs functionalized with amine group & $\mathrm{Na}_{2} \mathrm{SO}_{4}, \mathrm{NaCl}, \mathrm{MgSO} 4, \mathrm{BSA}$ & SEM,AFM, water contact angle, zeta potential & [240] \\
\hline 41 & PES & Acid oxidized MWCNTs & $\mathrm{BSA}, \mathrm{Na}_{2} \mathrm{SO}_{4}, \mathrm{MgSO}_{4}, \mathrm{NaCl}$ & SEM,FTIR, AFM, contact angle & [241] \\
\hline 42 & PES & Polycaprolactone modified MWCNTs & Cadmium ion & SEM, TGA, TEM, AFM, SEM, contact angle & [87] \\
\hline
\end{tabular}

Table 3: Carbon based polymer nanocomposites.

conductivity, large surface area, electromagnetic properties, good tensile and mechanical strength [151-153]. Graphene oxide based membranes are used in gas and ion separation due to their ability to stack into layers thus forming nanochannels which serve as pores for transport of highly selective ions and molecules. Surface modification of graphene oxide due to oxygen containing functional groups present on edge and basal plane results in enhancement of its properties like antifouling, antibacterial and selectivity hence provides good path for generation of new nano-composite membranes [154,155]. Although exact mechanism of GO antibacterial action is still unknown but it is assumed that bacterial growth is inhibited due to formation of Reactive Oxygen Species (ROS) from water and oxygen which disrupts bacterial integrity and proliferate through membrane into bacterial DNA thus inhibiting its replication, oxidizes proteins, inactivating enzymes results in their denaturation (Figure 12) [156].

Graphene oxide with metal and metal oxides: Although graphene oxide is considered as an antibacterial agent on its own and shows resistance against fungi, bacteria but some reports showed that GO is a weak antibacterial agent or it assists in the formation of bacterial biofilm or its proliferation. So it combines with other biocidal agents such as metal or metal oxides to form graphene oxide based nano-composites such as copper-GO, silver-GO etc. to show extraordinary antibacterial properties [157]. Loading of metal oxide on to graphene oxide results in various applications such as stability, thermal, reproducibility, magnetic, optical, mechanical properties in nanotechnology and nanomaterials $[158,159]$.

Li et al. [159] fabricated PVDF membrane with GO-Ag nanoparticles which showed enhanced antibacterial property, hydrophilicity and permeability. Liu et al. [160] investigated the dispersion of GO within

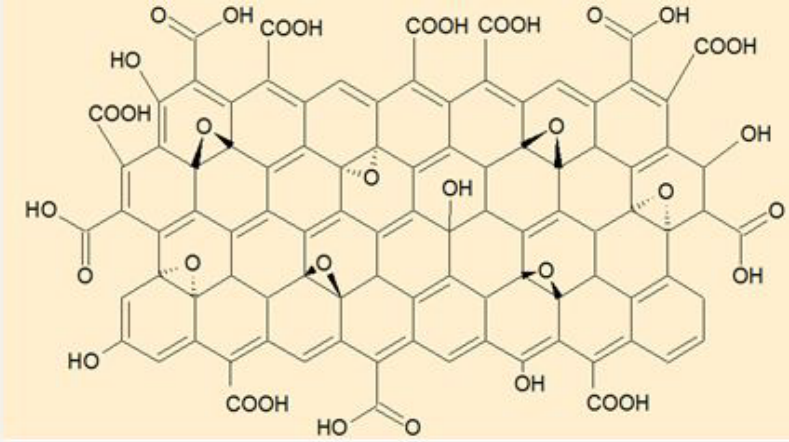

Figure 12: Structure of Graphene Oxide (GO).

polymeric membranes which shows high antibacterial activity due to inhibitory activity towards E. coli. Graphene oxide shows antibacterial activity as compared to other graphene based materials such as graphite oxide, graphite, and reduced graphene oxide. Qian et al. [161] fabricated sulfonated GO based membrane doped with $\mathrm{TiO}_{2}$ and $\mathrm{Ag}$ nanoparticles which showed high photocatalytic activity and wetability.

Fan et al. [162] prepared Silver/Graphene Oxide Polyvinyldene Fluoride (Ag/GO PVDF) membrane through wet spinning method and their results revealed that $\mathrm{Ag} / \mathrm{GO}-\mathrm{PVDF}$ membranes have asymmetric structure with 2.9 times higher flux for normal organic matter and 8.2 times for E. coli as compared to normal PVDF membrane due to its greater pore size. Ag/GO doped membrane has more hydrophilicity, high mechanical and tensile strength with enhanced antimicrobial 
activity. Andreia et al. [163] prepared thin film nano-composite membrane doped with Ag/GO NPs. They demostrated that the inactivation rate of TFC $\mathrm{Ag} / \mathrm{GO}$ membranes against Pseudomonas aeruginosa cells is about $80 \%$.These membranes possessed good antibiofouling properties Mahendra et al. [164] prepared $\mathrm{TiO}_{2} / \mathrm{GO}$ based poly sulfone ultrafiltration membranes to remove humic acid. The results revealed that the structure of membrane is asymmetric and have better ability to remove HA from the aqueous solution with good antifouling property. Fouling of $\mathrm{HA}$ was reduced with increase in $\mathrm{TiO}_{2} /$ GO NPs loading. Antibiofouling property of polysulfone membrane was also enhanced by the incorporation of $\mathrm{TiO}_{2} / \mathrm{GO} \mathrm{NPs}$.

Jin et al. [165] fabricated composite polyamide thin film membrane with GO for forward osmosis. Resulted membrane shows increased chlorine resistance, improved anti-biofouling behaviour and enhanced water permeability. Graphene oxide (GO) incorporation into polyamide layer (PA) changes its surface charge, hydrophilicity, layer thickness. Enhancement in the performance of TFC-GO membrane was attributed to both concentration and size of GO.

Zhang et al. [166] fabricated graphene oxide quantum dots (GOQDs) dispersed within thin film nano-composite membrane via interfacial polymerization for low pressure nano-filtration membranes. Their results demonstrated that GOQDs membranes with smooth surface have more hydrophilicity, more porosity, high antifouling property and good stability during the filtration process. They suggested that GOQDs are good filler for the best performance of the TFN membranes. Kim et al. [167] prepared highly crosslinked polymer GO membrane for chlorine tolerance. In membrane fabrication, poly (N-isopropylacrylamide-Co-N, N0-methylene-bisacrylamide polymer was used. These membranes have high performance in forward osmosis (FO) process with high mechanical stability, high water flux, less thickness, more porous and $99 \%$ rejection for $\mathrm{NaCl}$. In $\mathrm{FO}$ the salt rejection checked by reverse salt flux by this membrane was high. Andreia Fonseca et al. [168] prepared cellulose acetate (CA) membrane embedded with $\mathrm{Ag} / \mathrm{GO}$ nano-composites. Their results revealed that $\mathrm{Ag} / \mathrm{GO} \mathrm{CA}$ membranes possess large pore size and best antibacterial activity because it inactivates $90 \%$ more bacteria as compared to pristine CA membranes. They studied that Ag-NPs oxidized in the presence of oxygen and the surface of $\mathrm{Ag} / \mathrm{GO}$ is a source for $\mathrm{Ag}$ ions for killing bacteria and provides resistance towards proliferation and bacterial attachment. These membranes showed high water flux and more hydrophilicity without change in membrane surface roughness (Figure 13).

Mahmoud Ghasemi et al. [169] fabricated di allyl dimethyl ammonium chloride (DADMAC) /GO Polysulfone (PSF) membranes by reversible addition fragmentation chain transfer polymerization reaction. These membranes consist of thin dense layer with smooth surface, having good stability, selectivity, high mechanical strength and thermal stability. Results revealed that GO-DADMAC PSF membrane shows high rejection for heavy metals such as $\mathrm{Cu}^{2+}$ and $\mathrm{Cd}^{2+}$ Lim et al. [170] prepared Dual-layered thin film composite polysulfone/graphene oxide membrane. Results revealed that prepared membrane showed high performance due to water permeability, high water flux, low contact angle and good hydrophilic character.

Wang et al. [171] prepared $\mathrm{TiO}_{2} / \mathrm{GO}$ thin film nanofiltration membranes via interfacial polymerization of piperazine and trimesoyl chloride followed by incorporation of $\mathrm{TiO}_{2} / \mathrm{GO}$ nanocomposites in polyamide layer. They concluded that membrane shows high performance when concentration of $\mathrm{TiO}_{2} / \mathrm{GO}$ nanoparticles was 0.2 wt \% with $98.8 \%$ rejection rate of $\mathrm{Na}_{2} \mathrm{SO}_{4}$. Resulted membrane showed high antifouling properties towards BSA and dyes, increase in permeate flux and hydrophilicity of membrane along with reduction in membrane surface roughness.

$\mathrm{Xu}$ et al. [172] synthesized N-doped, GO/TiO, (NRGT) nanocomposites based polysulfone ultrafiltration membranes by sol gel method. For the preparation of NGR NPs urea was used as source of nitrogen. Then these NRGT NPs (used as nano-fillers) were blend on the surface of polysulfone membranes. Their results demonstrated that these membranes consist of asymmetric structure with dense upper layer having high thermal and mechanical stability, reduction in hydrophobicity, good water permeability and enhanced anti-biofouling properties. Decrease in irreversible fouling by $7.6 \%$ and BSA rejection was also observed.

Antai et al. [173-187] fabricated nitrocellulose filter (NCF) membranes with multivalent metal cations incorporated within GO. The incorporation of metal cations $\left(\mathrm{Al}^{3+}, \mathrm{Cr}^{3+}, \mathrm{Mg}^{2+}, \mathrm{Cu}^{2+}\right)$ within GO was done via three different methods such as Pre-incorporation, Post-incorporation and Filter-incorporation. Metal cations used for membrane preparation used were non-toxic, environment friendly and cheap [188-194]. Their results revealed that when metal cations are incorporated within GO, resulted membranes were flexible with metal cations having no effect on GO membranes mechanical stability. They stated that metal cations act as crosslinking agents to hold GO nanosheets together [195-197]. Metal cations based GO membranes have more stability in water. Filter-incorporation method is widely used in industrial applications due to its low cost and easier to use. On comparison of metal cations properties they observed that $\mathrm{Al}^{3+}$ and $\mathrm{Mg}^{2+}$ based GO membranes possessed more properties as compared to $\mathrm{Cu}^{2+}$ and $\mathrm{Cr}^{3+}$ based GO membranes [198-205].

\section{Characterization Techniques}

Characterization of nano-materials and membrane material is done in order to get information about their nature, chemistry, morphology,
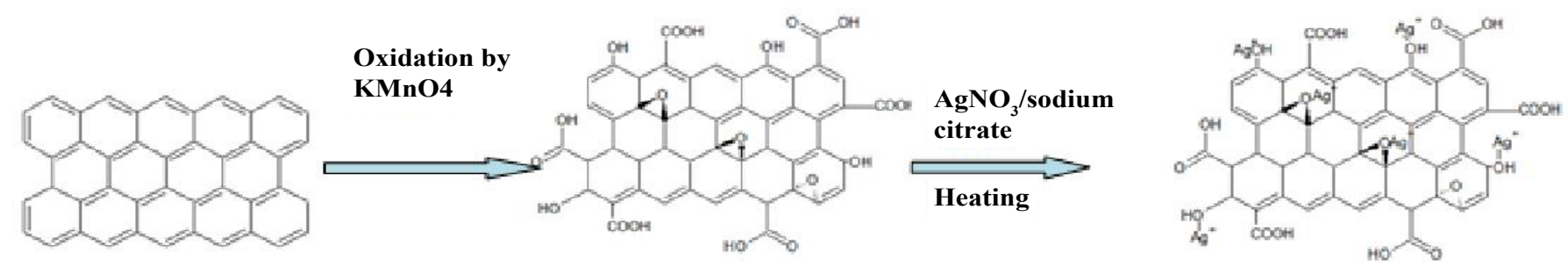

Figure 13: Functionalization of $\mathrm{GO}$ with $\mathrm{Ag}$ nanoparticles to form $\mathrm{GO} / \mathrm{Ag}$ nano-composite 
surface charge, wet ability, tensile strength, characteristics and types. Due to variable conditions such as fouling, chemical exposure, disintegration, cleaning etc. membrane performance decrease with the passage of time so characterization in this case using specific techniques gives valuable information about membrane structure and its topography in order to get insight about performance loss or affected membrane structure [206-211]. Similarly, modified membranes (modification with nano-materials) are also characterized in order to get information about modified surface layer for membrane performance.

Commonly used techniques and methods for characterization includes Scanning Electron Microscopy (SEM), Transmission Electron Microscopy (TEM), Fourier Transform-Infrared Spectroscopy (FTIR), X-Ray Diffraction (XRD), X-Ray Photo Electron Spectroscopy (XPS), Thermo-Gravimetric analysis (TGA), Energy Dispersive X-Ray Spectroscopy (EDX), Dynamic Light Scattering (DLS), Contact Angle, Porosity and Zeta Potential. Characterization is based on two parameters such as membrane performance (Permeability, Flux, Rejection, and Separation Factors) and membrane morphology (pore size, pore-size distribution, thickness of membrane, charge density, pore shape, chemical and physical properties).

\section{Scanning Electron Microscopy (SEM)}

Scanning electron microscopy is a commonly used tool for the determination of morphology and topography of membrane surface. In SEM, narrow beam of electrons scans across the membrane surface and deep inside. Image in SEM is produced due to combination of in elastically scattered secondary electrons and elastically backscattered electrons. Due to deep penetration of electron beam (backscattered electrons) gives valuable information about composition of specimen whereas secondary electrons being sensitive to topographic areas give information about membrane surface [212]. To get information about top layer and cross sectional parts (for membrane thickness), analysis of membrane is done through secondary and back scattered electrons. Magnification power of SEM is 100,000 and resolution is up to $0.1 \mu \mathrm{m}$ whereas for advanced instruments such as Field- Emission Scanning Electron Microscopy (FESEM) resolution power is up to $2.5 \mathrm{~nm}$. Signals produced after scanning sample are amplified, analyzed and converted into image. Final image of topography is shown on Cathode Ray Tube (CRT) detector. SEM with Energy Dispersive X-Ray Spectroscopy (EDX) is used for analysis of nanoparticles or type of elements on the membrane surface. In EDX characteristic X-rays are used. EDX can analyze composition at different depth of the membrane. EDX spectra are usually plotted between intensity and energy.

\section{FT-IR; XRD}

For spectral characterization X-RD and FT-IR techniques are used. To investigate the structural characteristics or crystallinity of polymer or nano-composite membrane, $\mathrm{X}-\mathrm{RD}$ is the best tool as it is a non-destructive technique. IR spectroscopy is basically employed in order to get information about composition of membranes or presence of different functional groups on membrane surface [213,214]. FT-IR technique is used to determine the cross linking on the surface and to study the chemical structure of the membrane. In FT-IR, the molecular vibrations are analyzed when infrared (IR) radiations interact with the sample. It gives information about the protein adsorption, modified membrane whether it is functionalized or not and also gives information about the presence of new functional groups on the membrane surface. Most frequently mode used for FT-IR for the characterization of membrane is ATR.

\section{X-Ray photoelectron spectroscopy (XPS)}

X-ray Photoelectron Spectroscopy (XPS) also known as Elemental Spectroscopy for Chemical Analysis (ESCA) is used for determining chemical composition of membrane. In XPS sample is placed under ultrahigh vacuum and X-rays are focused on the sample. Sample should be dry before placing into vacuum. The interaction of X-rays with sample causes photo emission of core electrons and binding energies of elements are also determined. The scanning spectrum of XPS is between the intensity and binding energy. All elements except hydrogen can be characterized by XPS and qualitative or quantitative information can be obtained $[215,216]$. XPS is more surface sensitive technique as compared to FT-IR. XPS technique is powerful tool to determine the relative abundance of different functional groups, thin membrane layers, nanofiltration membrane structures and modifications of membrane surfaces. XPS analysis is non-destructive due to the low energy of $\mathrm{X}$-rays and without conductive coating polymeric membranes can be analyzed. The analysis time of XPS is short because long time exposure of radiations can cause damage to membrane surface or sample. XPS can also be used for depth analysis of membrane but has limitation because it can cause damage to the membrane sample.

\section{Transmission electron microscopy (TEM)}

The basic building blocks of membrane can be examined by transmission electron microscopy. Through TEM quantitative information of particle, size distribution, morphology, and grain size can be obtained. The principle of TEM is little bit different from SEM. In TEM technique transmitted electron gives information about the size of nanoparticles [217-219]. The limitation of TEM technique is that it characterizes only thin film samples rather than whole membrane. DLS is another characterization technique for determination of nanoparticles size. The size of colloidal particles larger than nano scale and DLS analysis is useful for the size determination in colloidal suspensions. DLS characterization has done before going to TEM analysis to get information about nano scale particles.

\section{Zeta potential analysis}

Measurement of charge on membrane surface is termed as zeta potential. Zeta potential greatly influences membranes performance and determines extent of fouling [220-223]. Higher zeta potential means less chance of fouling due to greater repulsion between negative surface charge of membrane and hydrophobic foulants (e.g. proteins, humic acid due to negative charges). Malvern Zetasizer Nano equipped with DLS instrument cannot be used for solid surface zeta potential measurements but this device is important to determine the surface charge density of liquid and colloidal suspension [224-226]. Zeta potential technique is employed for checking stability of the membrane. If the value of zeta potential is higher than membrane has more stability and when the value of zeta potential is lower than membrane has less stability.

\section{Atomic force microscopy (AFM)}

Membrane surface roughness can be analyzed by Atomic Force Microscopy (AFM). AFM is the important tool for the determination of the surface topology. The most common implementation of this technique uses a cantilever with a sharp tip to scan over sample surface to get image at atomic level. By using AFM technique, surface charges and van der wall forces between the tip and membrane surface can be estimated. In AFM, three types of modes can be used contact mode, non-contact mode and tapping mode. Contact mode causes damage to membrane surface that's why usually tapping mode is used for 
the characterization of membrane surface. Through AFM technique roughness, pore size, pore-size distribution and phases on the surface of membranes can be determined. AFM characterization can also give information about the fouling and antifouling behavior of membrane as these properties depend on the surface smoothness.

\section{Thermo gravimetric analysis (TGA)}

In order to measure thermal stability of membrane with temperature variation, thermo gravimetric analysis (TGA) technique is used [227231]. Thermal properties of membrane should be higher. To check the thermal stability of membrane; membranes are heated above room temperature. With increase in temperature the degradation, dissolution and dissociation of membrane should not proceed. Thermal properties of modified and unmodified membrane can be compare or analyze by TGA method.

\section{Bubble point method}

For determination of pore radius bubble point method is used. In this method the original liquid is replaced by air in the porous membrane to characterize the pore size and radius of the membrane and pressure is applied to replace the liquid with air. Liquid Liquid Displacement Porosimetry (LLDP) is a method used to get information about the pore size distribution of membranes. The porosity of membrane can be characterized by dry wet method. In this method the weight of dry and wet samples are measured and then difference is taken of both dry and wet samples weight. Barrett-Joyner-Halenda (BJH) model has been used for pore size distribution of nanoparticles of titania and zirconia [232-234]. Brunauer-Emmett-Teller (BET) model is used to analyze porosity and pore size surface area of nanoparticles of metals or their oxides and composites. Nitrogen absorption/desorption method can be used to measure the pore size distribution by determination of absorption and desorption isotherms of nitrogen (gas).

\section{Contact angle}

Contact angle is used to find out hydrophilic and hydrophobic behavior of membrane. Hydrophilicity of membrane plays an important role in surface characterization of membrane and affects membrane performance. In contact angle the interfacial tensions are measured between interfaces. If water droplet spread more on the membrane surface then membrane is hydrophilic and the contact angle is less than 900 where water droplet taken as reference [235-241]. If membrane surface is hydrophobic then contact angle will be greater than $90^{\circ}$ and water droplet will not spread on the surface of membrane due to repulsive forces between membrane surface and water droplet. Contact angle measures wetting, flotation, enhanced oil recovery, cleaning technologies, super-hydrophobicity and liquid spreading properties of membrane. Contact angle also tells about antifouling behavior of membrane. Jing et al. measured contact angle of PES membranes embedded with titanium and zirconium. Deionized water was placed on the membrane surface and the contact angle measured was $48^{\circ}$ using sessile drop method [121].

\section{Conclusion}

This review article focused on resolving water scarcity problem via membrane technology. Major problem of membranes such as fouling, biofouling has been highlighted and their mitigation can be achieved through fabrication of polymer-nanocomposite membranes. Phase inversion is commonly exploited process for casting membranes using different novel metals and carbon based nanomaterials. Characterization of these nanocomposites membrane can be done with various techniques discussed in end section of review article. Membrane separation processes are therefore employed in water treatment due to their unique properties.

\section{References}

1. Watkins K (2006) Human development report: United Nations development programme.

2. Water $U$ (2007) Coping with water scarcity: Challenge of the twenty-first century. Prepared for World Water Day.

3. Urgency U (2007) Water caucus summary.World Water Council (WWC), Marseille, France.

4. WHO U (2010) Millennium development goals: Progress on sanitation and drinking-water: 2010 update report, geneva: WHO/UNICEF joint monitoring programme for water supply ISBN 9789241563956.

5. Lalia BS, Kochkodan V, Hashaikeh R, Hilal N (2013) A review on membrane fabrication: structure, properties and performance relationship. $\mathrm{J}$ desal 326 : 77-95.

6. Pendergast MM, Hoek EM (2011) A review of water treatment membrane nanotechnologies. Energy Environ. Sci 4: 1946-1971.

7. Li D, Yan Y, Wang $H(2016)$ Recent advances in polymer and polymer composite membranes for reverse and forward osmosis processes. J Prog Polym Sci 61 : 104-155.

8. Luo J, Cao W, Ding L, Zhu Z, Wan Y, et al. (2012) Treatment of dairy effluent by shear-enhanced membrane filtration: The role of foulants. J Seppur 96 194-203.

9. Yan Y, Li D, Wang H (2016) Advances in polymer and polymer composite membranes for forward and reverse osmosis processes. Prog Polym Sci 16: 104-125.

10. Mezher T, Fath $H$, Abbas Z, Khaled A (2011) Techno-economic assessment and environmental impacts of desalination technologies. J Desal 266: 263-273.

11. Shi W, He B, Ding J, Li J, Yan F, et al. (2010) Preparation and characterization of the organic-inorganic hybrid membrane for biodiesel production. Bioresour Technol 101: 1501-1505.

12. Joshi R, Alwarappan S, Yoshimura M, Sahajwalla V, Nishina Y (2015) Graphene oxide: The new membrane material. J apmt 1: 1-12.

13. Ulbricht M (2006) Advanced functional polymer membranes. J Polymer 47 2217-2262.

14. Yampolskii $Y$ (2012) Polymeric gas separation membranes. Macromolecules 45: 3298-3311.

15. Rao M, Sircar S (1996) Performance and pore characterization of nanoporous carbon membranes for gas separation. J MemSci 110: 109-118.

16. Farrell S, Sirkar KK (2001) Mathematical model of a hybrid dispersed networkmembrane-based controlled release system. Journal of Controlled Release 70 $51-61$.

17. Jhaveri JH, Murthy Z (2016) A comprehensive review on anti-fouling nanocomposite membranes for pressure driven membrane separation processes. J Desal 379: 137-154.

18. Kochkodan V, Johnson DJ, Hilal N (2014) Polymeric membranes: Surface modification for minimizing (bio) colloidal fouling. Adv Colloid Interface Sci 206 116-140.

19. Drioli E, Fontananova E (2009) Integrated membrane processes. Membrane Operations: Innovative Separations and Transformations 265-283.

20. Barth C, Goncalves M, Pires A, Roeder J, Wolf B (2000) Asymmetric polysulfone and polyethersulfone membranes: Effects of thermodynamic conditions during formation on their performance. J MemSci 169: 287-299.

21. Zhao C, Xue J, Ran F, Sun S (2013) Modification of polyethersulfone membranes-a review of methods. Progress in Materials Science 58: 76-150.

22. Ravishankar H, Roddick F, Navaratna D, Jegatheesan V (2018) Preparation characterization and critical flux determination of graphene oxide blended Polysulfone (PSF) membranes in an MBR system. J Environ Manage 213: 168-179.

23. Gao H, Sun X, Gao C (2017) Antifouling polysulfone ultrafiltration membranes 
with sulfobetaine polyimides as novel additive for the enhancement of both water flux and protein rejection. J Mem Sci 542: 81-90.

24. Hwang J, Choi J, Kim JM, Kang SW (2016) Water treatment by polysulfone membrane modified with tetrahydrofuran and water pressure. Macromol Res 24: $1020-1023$.

25. Xiao Y, Liu X, Wang D, Lin Y, Han Y, et al. (2013) Feasibility of using an innovative PVDF MF membrane prior to RO for reuse of a secondary municipal effluent. J Desal 311: 16-23.

26. Hou J, Dong G, Ye Y, Chen V (2014) Enzymatic degradation of bisphenol-A with immobilized laccase on TiO2 sol-gel coated PVDF membrane. J Mem Sci 469: 19-30.

27. Kang G, Cao Y (2014) Application and modification of poly (vinylidene fluoride) (PVDF) membranes-a review. J Mem Sci 463: 145-165.

28. Zaviska F, Drogui P, Grasmick A, Azais A, Heran M (2013) Nanofiltration membrane bioreactor for removing pharmaceutical compounds. J Mem Sci 429: 121-129.

29. Nevstrueva D, Pihlajamaki A, Manttari M (2015) Effect of a TiO2 additive on the morphology and permeability of cellulose ultrafiltration membranes prepared via immersion precipitation with ionic liquid as a solvent. Cellulose 22: 3865-3876.

30. Liu F, Abed MM, Li K (2011) Preparation and characterization of poly (vinylidene fluoride) (PVDF) based ultrafiltration membranes using nano $\mathrm{y}-\mathrm{Al} 2 \mathrm{O} 3$. MemSci 366: 97-103

31. Oh SJ, Kim N, Lee YT (2009) Preparation and characterization of PVDF/TiO2 organic-inorganic composite membranes for fouling resistance improvement. J Mem Sci 345: 13-20.

32. Bernardo P, Drioli E, Golemme G (2009) Membrane gas separation: A review/ state of the art. Ind Eng Chem Res 48: 4638-4663.

33. Ahmad A, Jawad Z, Low S, Zein S (2014) A cellulose acetate/multi-walled carbon nanotube mixed matrix membrane for $\mathrm{CO} 2 / \mathrm{N} 2$ separation. J MemSci 451: 55-66.

34. Goetz LA, Jalvo B, Rosal R, Mathew AP (2016) Superhydrophilic anti-fouling electrospun cellulose acetate membranes coated with chitin nanocrystals for water filtration. J Mem Sci 510: 238-248.

35. Yu Y, Wu QY, Liang HQ, Gu L, Xu ZK (2017) Preparation and characterization of cellulose triacetate membranes via thermally induced phase separation. $J$ App Polym Sci 134

36. Kochkodan V, Hilal N (2015) A comprehensive review on surface modified polymer membranes for biofouling mitigation. J Desal 356: 187-207.

37. Rezakazemi M, Dashti A, Harami HR, Hajilari N (2018) Fouling-resistan membranes for water reuse. Environ Chem Letters: 1-49.

38. Rezakazemi M, Khajeh A, Mesbah M (2017) Membrane filtration of wastewater from gas and oil production. Environ Chem Letters: 1-22.

39. Van de Lisdonk C, Van Paassen J, Schippers J (2000) Monitoring scaling in nanofiltration and reverse osmosis membrane systems. J Desal 132: 101-108.

40. Guo W, Ngo HH, Li J (2012) A mini-review on membrane fouling. Bioresour Technol 122: 27-34.

41. Al-Amoudi AS, Farooque AM (2005) Performance restoration and autopsy of NF membranes used in seawater pretreatment. J Desal 178: 261-271.

42. Meng F, Chae SR, Drews A, Kraume M, Shin HS, et al. (2009) Recent advances in membrane bioreactors (MBRs): Membrane fouling and membrane material. Water Res 43: 1489-1512.

43. Nilson JA, DiGiano FA (1996) Influence of NOM composition on nanofiltration American Water Works Association Journal 88: 53.

44. Vrijenhoek EM, Hong S, Elimelech M (2001) Influence of membrane surface properties on initial rate of colloidal fouling of reverse osmosis and nanofiltration membranes. J Mem Sci 188: 115-128.

45. Flemming HC, Schaule G (1988) Biofouling on membranes-a microbiological approach. J Desal 70: 95-119.

46. Chen V, Mansouri J, Charlton T (2010) Biofouling in membrane systems. Membrane Technology: Membranes for Water Treatment 4: 25-51.

47. Misdan N, Ismail AF, Hilal N (2016) Recent advances in the development of (bio) fouling resistant thin film composite membranes for desalination. J Desal 380: 105-111.

48. Li Q, Elimelech M (2004) Organic fouling and chemical cleaning of nanofiltration membranes: Measurements and mechanisms. Environ Sci Technol 38: 4683-4693.

49. Demirkol GT, Dizge N, Acar TO, Salmanli OM, Tufekci N (2017) Influence of nanoparticles on filterability of fruit-juice industry wastewater using submerged membrane bioreactor. Water Sci Technol 76: 705-711.

50. Lee J, Chae HR, Won YJ, Lee K, Lee CH, et al. (2013) Graphene oxide nanoplatelets composite membrane with hydrophilic and antifouling properties for wastewater treatment. J MemSci 448: 223-230.

51. Xu Z, Zhang J, Shan M, Li Y, Li B, et al. (2014) Organosilane-functionalized graphene oxide for enhanced antifouling and mechanical properties of polyvinylidene fluoride ultrafiltration membranes. J Mem Sci 458: 1-13.

52. Paul D, Robeson LM (2008) Polymer nanotechnology: Nanocomposites. J Polymer 49: 3187-3204.

53. Zodrow K, Brunet L, Mahendra S, Li D, Zhang A, et al. (2009) Polysulfone ultrafiltration membranes impregnated with silver nanoparticles show improved biofouling resistance and virus removal. Water Res 43: 715-723.

54. Damodar RA, You SJ, Chou HH (2009) Study the self-cleaning, antibacteria and photocatalytic properties of $\mathrm{TiO} 2$ entrapped PVDF membranes. J Hazardous Mater 172: 1321-1328.

55. Yu Z, Liu X, Zhao F, Liang X, Tian Y (2015) Fabrication of a low-cost nano-SiO2/ PVC composite ultrafiltration membrane and its antifouling performance. J App Polym Sci 132: 41267

56. Yin J, Deng B (2015) Polymer-matrix nanocomposite membranes for wate treatment. J Mem Sci 479: 256-275.

57. Vatanpour V, Madaeni SS, Khataee AR, Salehi E, Zinadini S, et al. (2012) $\mathrm{TiO} 2$ embedded mixed matrix PES nanocomposite membranes: Influence of different sizes and types of nanoparticles on antifouling and performance. Desal 292: 19-29.

58. Pourjafar S, Rahimpour A, Jahanshahi M (2012) Synthesis and characterization of PVA/PES thin film composite nanofiltration membrane modified with TiO2 nanoparticles for better performance and surface properties. JIEC 18: $1398-1405$

59. Zargar M, Hartanto Y, Jin B, Dai S (2017) Understanding functionalized silica nanoparticles incorporation in thin film composite membranes: Interactions and desalination performance. J MemSci 521: 53-64.

60. Ng LY, Mohammad AW, Leo CP, Hilal N (2013) Polymeric membranes incorporated with metal/metal oxide nanoparticles: A comprehensive review. J Desal 308: 15-33.

61. Kim SG, Hyeon DH, Chun JH, Chun BH, Kim SH (2013) Nanocomposite poly (arylene ether sulfone) reverse osmosis membrane containing functional zeolite nanoparticles for seawater desalination. J Memb Sci 443: 10-18.

62. Jung JT, Kim JF, Wang HH, di Nicolo E, Drioli E, et al. (2016) Understanding the non-solvent induced phase separation (NIPS) effect during the fabrication of microporous PVDF membranes via thermally induced phase separation (TIPS). J Memb Sci 514: 250-263.

63. Rezakazemi M, Sadrzadeh M, Mohammadi T, Matsuura T (2017) Methods for the preparation of organic-inorganic nanocomposite polymer electrolyte membranes for fuel cells, in Organic-inorganic composite polymer electrolyte membranes. Springer 311-325.

64. Rezakazemi M, Sadrzadeh M, Matsuura T (2018) Thermally stable polymers for advanced high-performance gas separation membranes. Prog Energy Combust Sci 66: 1-41.

65. Liu F, Hashim NA, Liu Y, Abed MM, Li K (2011) Progress in the production and modification of PVDF membranes. J Memb Sci 375: 1-27.

66. Aburabie J, Villalobos LF, Peinemann KV (2017) Composite membrane formation by combination of reaction-induced and nonsolvent-induced phase separation. Macromol Mater Eng 302.

67. Castro AJ (1981) Methods for making microporous products. Google Patents.

68. Kim JF, Jung JT, Wang HH, Lee SY, Moore T, et al. (2016) Microporous PVDF membranes via thermally induced phase separation (TIPS) and stretching methods. J Memb Sci 509: 94-104. 
69. Liu Z, Cui Z, Zhang Y, Qin S, Yan F, et al. (2017) Fabrication of polysulfone membrane via thermally induced phase separation process. Mater Lett 195 : 190-193.

70. Sun Y, Rajabzadeh S, Ma W, Zhou Z, Kakihana Y, et al. (2016) Preparation of PVDF/poly (tetrafluoroethylene-co-vinyl alcohol) blend membranes with antifouling propensities via nonsolvent induced phase separation method. $J$ Appl Polym Sci 133: 43780-43789.

71. Guillen GR, Pan Y, Li M, Hoek EM (2011) Preparation and characterization of membranes formed by nonsolvent induced phase separation: A review. Ind Eng Chem Res 50: 3798-3817.

72. Liang HQ, Wu QY, Wan LS, Huang XJ, Xu ZK (2013) Polar polymer membranes via thermally induced phase separation using a universal crystallizable diluent. J Memb Sci 446: 482-491.

73. Othman N, Harruddin N, Idris A, Ooi ZY, Fatiha N, et al. (2016) Fabrication of polypropylene membrane via thermally induced phase separation as a support matrix of tridodecylamine supported liquid membrane for Red 3BS dye removal. Desalination and Water Treatment 57: 12287-12301.

74. Rajabzadeh S, Maruyama T, Ohmukai Y, Sotani T, Matsuyama H (2009) Preparation of PVDF/PMMA blend hollow fiber membrane via thermally induced phase separation (TIPS) method. Sep Purif Technol 66: 76-83.

75. Zhao YF, Zhang PB, Sun J, Liu CJ, Yi Z, et al. (2015) Versatile antifouling polyethersulfone filtration membranes modified via surface grafting of zwitterionic polymers from a reactive amphiphilic copolymer additive. J Colloid Interface Sci 448: 380-388.

76. Ding H, Tian Y, Wang L, Liu B (2007) Preparation of ultrahigh-molecular-weigh polyethylene membranes via a thermally induced phase-separation method. $\mathrm{J}$ Appl Polym Sci 105: 3355-3362.

77. Menut P, Su Y, Chinpa W, Pochat-Bohatier C, Deratani A, et al. (2008) A top surface liquid layer during membrane formation using vapor-induced phase separation (VIPS)—evidence and mechanism of formation. J Memb Sci 310: 278-288.

78. Peng Y, Fan H, Dong Y, Song Y, Han H (2012) Effects of exposure time on variations in the structure and hydrophobicity of polyvinylidene fluoride membranes prepared via vapor-induced phase separation. Appl Surf Sci 258: 7872-7881.

79. Zhao Y, Xu Z, Shan M, Min C, Zhou B, et al. (2013) Effect of graphite oxide and multi-walled carbon nanotubes on the microstructure and performance of pvdf membranes. Sep Purif Technol 103: 78-83.

80. Zinadini S, Zinatizadeh A, Rahimi M, Vatanpour V (2017) Magnetic fieldaugmented coagulation bath during phase inversion for preparation of ZNFe2O4/SiO2/PES nanofiltration membrane: A novel method for flux enhancement and fouling resistance. J IND ENG CHEM 46: 9-18.

81. Susanto H, Ulbricht M (2009) Characteristics, performance and stability of polyethersulfone ultrafiltration membranes prepared by phase separation method using different macromolecular additives. J Memb Sci 327: 125-135.

82. Zhang J, Xu Z, Mai W, Min C, Zhou B, et al. (2013) Improved hydrophilicity, permeability, antifouling and mechanical performance of PVDF composite ultrafiltration membranes tailored by oxidized low-dimensional carbon nanomaterials. J Mat Chem 1: 3101-3111.

83. Telford AM, James M, Meagher L, Neto C (2010) Thermally cross-linked PNVP films as antifouling coatings for biomedical applications. ACS Appl Mater Interfaces 2: 2399-2408.

84. Qin Q, Hou Z, Lu X, Bian X, Chen L, et al. (2013) Microfiltration membranes prepared from poly ( $n$-vinyl-2-pyrrolidone) grafted poly (vinylidene fluoride) synthesized by simultaneous irradiation. J Memb Sci 427: 303-310.

85. Ma Y, Shi F, Ma J, Wu M, Zhang J, et al. (2011) Effect of PEG additive on the morphology and performance of polysulfone ultrafiltration membranes. Desal 272: $51-58$.

86. Wang H, Yu T, Zhao C, Du Q (2009) Improvement of hydrophilicity and blood compatibility on polyethersulfone membrane by adding polyvinylpyrrolidone. Fibers and polymers 10: 1-5.

87. Mansourpanah Y, Madaeni S, Rahimpour A, Adeli M, Hashemi M, et al. (2011) Fabrication new PES-based mixed matrix nanocomposite membranes using polycaprolactone modified carbon nanotubes as the additive: Property changes and morphological studies. Desal 277: 171-177.
88. Chakrabarty B, Ghoshal A, Purkait M (2008) Effect of molecular weight of PEG on membrane morphology and transport properties. J Memb Sci 309: 209-221.

89. Idris A, Zain NM, Noordin M (2007) Synthesis, characterization and performance of asymmetric polyethersulfone (PES) ultrafiltration membranes with polyethylene glycol of different molecular weights as additives. Desal 207: 324-339.

90. Cheng XQ, Shao L, Lau CH (2015) High flux polyethylene glycol based nanofiltration membranes for water environmental remediation. J Memb Sci 476: 95-104.

91. Yunos MZ, Harun Z, Basri H, Ismail AF (2014) Studies on fouling by natura organic matter (NOM) on polysulfone membranes: Effect of polyethylene glycol (PEG). Desal 333: 36-44.

92. Wongchitphimon $S$, Wang $R$, Jiraratananon $R$, Shi L, Loh $\mathrm{CH}$ (2011) Effect of polyethylene glycol (PEG) as an additive on the fabrication of polyvinylidene fluoride-co-hexafluropropylene (PVDF-HFP) asymmetric microporous hollow fiber membranes. J Memb Sci 369: 329-338.

93. Tavakolmoghadam M, Rekabdar F, Hemmati M, Mohammadi T (2016) Poly (vinylidene fluride) membrane preparation and characterization: Effects of mixed solvents and PEG molecular weight. J Petro Sci Tech 6: 11-21.

94. Roy K, Anjali T, Sujith A (2017) Asymmetric membranes based on poly (vinyl chloride): Effect of molecular weight of additive and solvent power on the morphology and performance. J Mat Sci 52: 5708-5725.

95. Wu Y, Wu C, Li Y, Xu T, Fu Y (2010) PVA-silica anion-exchange hybrid membranes prepared through a copolymer crosslinking agent. J Memb Sci 350: 322-332.

96. Saljoughi E, Amirilargani M, Mohammadi T (2009) Effect of poly (viny pyrrolidone) concentration and coagulation bath temperature on the morphology, permeability, and thermal stability of asymmetric cellulose acetate membranes. J Appl Polym Sci 111: 2537-2544.

97. Vatsha B, Ngila JC, Moutloali RM (2014) Preparation of antifouling Polyvinyl Pyrrolidine (PVP 40k) modified polyethersulfone (PES) ultrafiltration (UF) membrane for water purification. Physics and Chemistry of the Earth 67: 125131.

98. Peydayesh M, Bagheri M, Mohammadi T, Bakhtiari O (2017) Fabrication optimization of polyethersulfone (PES)/Polyvinyl Pyrrolidine (PVP) nanofiltration membranes using box-behnken response surface method. RSC Advances 7 : 24995-25008.

99. Lee J, Park B, Kim J, Park SB (2015) Effect of PVP, lithium chloride, and glycerol additives on PVDF dual-layer hollow fiber membranes fabricated using simultaneous spinning of TIPS and NIPS. Macromol Res 23: 291-299.

100.Simone S, Figoli A, Criscuoli A, Carnevale M, Rosselli A, et al. (2010) Preparation of hollow fibre membranes from PVDF/PVP blends and their application in VMD. J Memb Sci 364: 219-232.

101. Yuan Z, Dan-Li X (2008) Porous PVDF/TPU blends asymmetric hollow fiber membranes prepared with the use of hydrophilic additive PVP $(k 30)$. Desal 223: $438-447$

102.Zhang Z, An Q, Liu T, Zhou Y, Qian J, et al. (2011) Fabrication of polysulfone ultrafiltration membranes of a density gradient cross section with good antipressure stability and relatively high water flux. Desal 269: 239-248.

103. Ma Y, Shi F, Wang Z, Wu M, Ma J, et al. (2012) Preparation and characterization of PSf/clay nanocomposite membranes with PEG 400 as a pore forming additive. Desal 286: 131-137.

104.Peeva PD, Million N, Ulbricht M (2012) Factors affecting the sieving behavior of anti-fouling thin-layer cross-linked hydrogel polyethersulfone composite ultrafiltration membranes. J Memb Sci 390: 99-112.

105. Jiang J, Zhu L, Zhu L, Zhang H, Zhu B, et al. (2013) Antifouling and antimicrobial polymer membranes based on bioinspired polydopamine and strong hydrogen-bonded poly (n-vinyl pyrrolidone). ACS Appl Mater Interfaces 5: 12895-12904.

106. Hou S, Xing J, Dong X, Zheng J, Li S (2017) Integrated antimicrobial and antifouling ultrafiltration membrane by surface grafting $P E O$ and $n$-chloramine functional groups. J Colloid Interface Sci 500: 333-340.

107. Khan AUHKhan Z, Aljundi IH (2017) Improved hydrophilicity and anti-fouling properties of polyamide tfn membrane comprising carbide derived carbon. Desal 420: 125-135. 
108. Yu H, Zhang Y, Sun $X$, Liu J, Zhang $H$ (2014) Improving the antifouling property of polyethersulfone ultrafiltration membrane by incorporation of dextran grafted halloysite nanotubes. J Chem Eng 237: 322-328.

109. Low ZX, Wang Z, Leong S, Razmjou A, Dumée LF, et al. (2015) Enhancement of the antifouling properties and filtration performance of poly (ethersulfone) ultrafiltration membranes by incorporation of nanoporous titania nanoparticles. Ind Eng Chem Res 54: 11188-11198.

110. Li Q, Pan S, Li X, Liu C, Li J, et al. (2015) Hollow mesoporous silica spheres/ polyethersulfone composite ultrafiltration membrane with enhanced antifouling property. Colloids Surf A 487: 180-189.

111. Park SY, Chung JW, Chae YK, Kwak SY (2013) Amphiphilic thiol functiona linker mediated sustainable anti-biofouling ultrafiltration nanocomposite comprising a silver nanoparticles and poly (vinylidene fluoride) membrane. ACS Appl Mater Interfaces 5: 10705-10714

112. Sile-Yuksel M, Tas B, Koseoglu-Imer DY, Koyuncu I (2014) Effect of silver nanoparticle $(\mathrm{AgNp})$ location in nanocomposite membrane matrix fabricated with different polymer type on antibacterial mechanism. Desal 47: 120-130.

113. Lowry GV, Gregory KB, Apte SC, Lead JR (2012) Transformations of nanomaterials in the environment. Environ Sci Technol 46: 6893-6899.

114. Rezakazemi M, Amooghin AE, Montazer-Rahmati MM, Ismail AF, Matsuura $T$ (2014) State-of-the-art membrane based CO2 separation using mixed matrix membranes (MMMs): An overview on current status and future directions. Prog Polym Sci 39: 817-861.

115. Rajasekhar T, Trinadh M, Babu PV, Sainath AVS, Reddy A (2015) Oil-wate emulsion separation using ultrafiltration membranes based on novel blends of poly (vinylidene fluoride) and amphiphilic tri-block copolymer containing carboxylic acid functional group. J Memb Sci 481: 82-93.

116. Zhan X, Zhang G, Chen X, He R, Zhang Q, et al. (2015) Improvement of antifouling and antibacterial properties of poly (ether sulfone) UF membrane by blending with a multifunctional comb copolymer. Ind Eng Chem Res 54: 11312-11318.

117. Rostam AB, Peyravi M, Ghorbani M, Jahanshahi M (2018) Antibacterial surface modified of novel nanocomposite sulfonated polyethersulfone/polyrhodanine membrane. Appl Surf Sci 427: 17-28.

118. Alpatova A, Meshref M, McPhedran KN, El-Din MG (2015) Composite polyvinylidene fluoride (pvdf) membrane impregnated with $\mathrm{Fe} 2 \mathrm{O} 3$ nanoparticles and multiwalled carbon nanotubes for catalytic degradation of organic contaminants. J Memb Sci 490: 227-235.

119. Arsuaga JM, Sotto Adel Rosario G, Martínez A, Molina S, et al. (2013) Influence of the type, size, and distribution of metal oxide particles on the properties of nanocomposite ultrafiltration membranes. J Memb Sci 428: 131-141.

120.Wu Y, Liu X, Cui J, Meng M, Dai J, et al. (2017) Bioinspired synthesis of high-performance nanocomposite imprinted membrane by a polydopamineassisted metal-organic method. J Hazard Mater 323: 663-673.

121.Das MR, Sarma RK, Saikia R, Kale VS, Shelke MV, et al. (2011) Synthesis of silver nanoparticles in an aqueous suspension of graphene oxide sheets and its antimicrobial activity. Colloids and Surfaces B Biointerfaces 83: 16-22.

122.Pan Y, Yu Z, Shi H, Chen Q, Zeng G, et al. (2017) A novel antifouling and antibacterial surface $\square$ functionalized PVDF ultrafiltration membrane via binding Ag/SiO2 nanocomposites. J Chem Technol Biotechnol 92: 562-572.

123. Ben-Sasson M, Zodrow KR, Genggeng Q, Kang Y, Giannelis EP, et al. (2013) Surface functionalization of thin-film composite membranes with coppe nanoparticles for antimicrobial surface properties. Environ Sci Technol 48 384-393.

124. Li B, Li Y, Zhao Y, Sun L (2013) Shape-controlled synthesis of Cu2O nano/ microcrystals and their antibacterial activity. J Phys Chem Solids 74: 18421847.

125. Chen Y, Zhang Y, Liu J, Zhang H, Wang K (2012) Preparation and antibacterial property of polyethersulfone ultrafiltration hybrid membrane containing halloysite nanotubes loaded with copper ions. Chem Eng J 210: 298-308.

126.Zhang A, Zhang Y, Pan G, Xu J, Yan H, et al. (2017) In situ formation of copper nanoparticles in carboxylated chitosan layer: Preparation and characterization of surface modified TFC membrane with protein fouling resistance and longlasting antibacterial properties. Separation and Purification Technology 176: 164-172.
127. Hoseini SN, Pirzaman AK, Aroon MA, Pirbazari AE (2017) Photocatalytic degradation of 2, 4-dichlorophenol by co-doped TiO2 (CO/ TiO2) nanoparticles and $\mathrm{CO} / \mathrm{TiO} 2$ containing mixed matrix membranes. Journal of Water Process Engineering 17: 124-134.

128. Alzahrani S, Mohammad AW (2014) Challenges and trends in membrane technology implementation for produced water treatment: A review. Journal of Water Process Engineering 4: 107-133.

129. Kuvarega AT, Khumalo N, Dlamini D, Mamba BB (2018) Polysulfone/n, pd CO-doped $\mathrm{TiO} 2$ composite membranes for photocatalytic dye degradation. Separation and Purification Technology 191: 122-133.

130.Zhao S, Yan W, Shi M, Wang Z, Wang J, et al. (2015) Improving permeability and antifouling performance of polyethersulfone ultrafiltration membrane by incorporation of $\mathrm{ZnO}-\mathrm{DMF}$ dispersion containing nano- $\mathrm{ZnO}$ and polyvinylpyrrolidone. J Mem Sci 478: 105-116.

131. Bojarska M, Nowak B, Skowroński J, Piątkiewicz W, Gradoń L (2017) Growth of $\mathrm{ZnO}$ nanowires on polypropylene membrane surface-characterization and reactivity. Applied Surface Science 391: 457-467.

132. Liang S, Xiao K, Mo Y, Huang X (2012) A novel ZnO nanoparticle blended polyvinylidene fluoride membrane for anti-irreversible fouling. J Mem Sci 394 184-192.

133. Pintilie SC, Tiron LG, Birsan IG, Ganea D, Balta S (2017) Influence of $\mathrm{ZnO}$ nanoparticle size and concentration on the polysulfone membrane performance. Materiale Plastice 54: 257.

134.Zakeritabar SF, Jahanshahi M, Peyravi M (2018) Photocatalytic behavior of induced membrane by $\mathrm{ZrO} 2-\mathrm{SnO} 2$ nanocomposite for pharmaceutical wastewater treatment. Catal Lett: 1-12.

135.Lv Y, Yang HC, Liang HQ, Wan LS, Xu ZK (2016) Novel nanofiltration membrane with ultrathin zirconia film as selective layer. J Mem Sci 500 265-271

136. Li H, Huang Q Li D, Li S, Wu X, et al. (2018) The generation of a molecula imprinted membrane by coating cellulose acetate onto a ZrO2-modified alumina membrane for the chiral separation of mandelic acid enantiomers. Org Process Res Dev 22: 278-285.

137. Rezakazemi M, Shahidi K, Mohammadi T (2012) Sorption properties of hydrogen-selective PDMS/zeolite 4A mixed matrix membrane. Int J Hydrog Energy 37: 17275-17284.

138. Rezakazemi M, Shahidi K, Mohammadi T (2012) Hydrogen separation and purification using crosslinkable PDMS/zeolite A nanoparticles mixed matrix membranes. Int J Hydrog Energy 37: 14576-14589.

139. Yin Y, Deng W, Wang H, Li A, Wang C, et al. (2015) Fabrication of hybrid membranes by incorporating acid-base pair functionalized hollow mesoporous silica for enhanced proton conductivity. J Mater Chem 3: 16079-16088.

140.De Volder MF, Tawfick SH, Baughman RH, Hart AJ (2013) Carbon nanotubes: Present and future commercial applications. Science 339: 535-539.

141.Duan W, Chen G, Chen C, Sanghvi R, Iddya A, et al. (2017) Electrochemical removal of hexavalent chromium using electrically conducting carbon nanotube/polymer composite ultrafiltration membranes. J Mem Sci 531: 160171.

142. Chan WF, Marand E, Martin SM (2016) Novel zwitterion functionalized carbon nanotube nanocomposite membranes for improved RO performance and surface anti-biofouling resistance. J Mem Sci 509: 125-137.

143.Zhao Q, Hou J, Shen J, Liu J, Zhang Y (2015) Long-lasting antibacterial behavior of a novel mixed matrix water purification membrane. J Mater Chem 3: 18696-18705.

144. Wang J, Zhang P, Liang B, Liu Y, Xu T, et al. (2016) Graphene oxide as an effective barrier on a porous nanofibrous membrane for water treatment. ACS Appl Mater Interfaces 8: 6211-6218.

145.Liang B, Zhang P, Wang J, Qu J, Wang L, et al. (2016) Membranes with selective laminar nanochannels of modified reduced graphene oxide for wate purification. Carbon 103: 94-100.

146. Orooji Y, Faghih M, Razmjou A, Hou J, Moazzam P, et al. (2017) Nanostructured mesoporous carbon polyethersulfone composite ultrafiltration membrane with significantly low protein adsorption and bacterial adhesion. Carbon 111: 689-704

147. Tiraferri A, Vecitis CD, Elimelech M (2011) Covalent binding of single- 
walled carbon nanotubes to polyamide membranes for antimicrobial surface properties. ACS Appl Mater Interfaces 3: 2869-2877

148. Li Y, Gao Y, Yang C, Wang Z, Xue G (2014) Facile and controllable assembly of multiwalled carbon nanotubes on polystyrene microspheres. Chinese Journal of Polymer Science 32: 711-717.

149. Kumar HV, Huang KYS, Ward SP, Adamson DH (2017) Altering and investigating the surfactant properties of graphene oxide. J Colloid Interface Sci 493: 365-370.

150. Liu G, Jiang W, Sun D, Wang Y, Li F (2014) One-pot synthesis of urchinlike n nanoparticles/rGO composites with extraordinary electromagnetic absorption properties. Appl Surf Sci 314: 523-529.

151.Zhu J, Wang J, Hou J, Zhang Y, Liu J, et al. (2017) Graphene-based antimicrobial polymeric membranes: A review. J Mater Chem 5: 6776-6793.

152. Fathizadeh M, Xu WL, Zhou F, Yoon Y, Yu M (2017) Graphene oxide: A novel 2-dimensional material in membrane separation for water purification. Advanced Materials Interfaces 4: 28990-29001.

153. Metin Ö, Aydoğan Ş, Meral K (2014) A new route for the synthesis of graphene oxide-Fe3O4 (GO- $\mathrm{Fe} 3 \mathrm{O} 4$ ) nanocomposites and their schottky diode applications. J Alloys Compd 585: 681-688.

154. Lim MY, Choi YS, Kim J, Kim K, Shin H, et al. (2017) Cross-linked graphene oxide membrane having high ion selectivity and antibacterial activity prepared using tannic acid-functionalized graphene oxide and polyethyleneimine. J Mem Sci 521: 1-9.

155. Zhao R, Lv M, Li Y, Sun M, Kong W, et al. (2017) Stable nanocomposite based on pegylated and silver nanoparticles loaded graphene oxide for long-term antibacterial activity. ACS Appl Mater Interfaces 9: 15328-15341.

156. Zhao Y, Lu J, Liu X, Wang Y, Lin J, et al. (2016) Performance enhancement of polyvinyl chloride ultrafiltration membrane modified with graphene oxide. $J$ Colloid Interface Sci 480: 1-8.

157. Liu X, Zhu H, Yang X (2011) An amperometric hydrogen peroxide chemica sensor based on graphene-Fe3O4 multilayer films modified to electrode. Talanta 87: 243-248.

158. Deosarkar M, Pawar S, Bhanvase B (2014) In situ sonochemical synthesis of $\mathrm{Fe} 3 \mathrm{O} 4$ graphene nanocomposite for lithium rechargeable batteries. Chemical Engineering and Processing: Process Intensification 83: 49-55.

159. Li J, Liu X, Lu J, Wang Y, Li G, et al. (2016) Anti-bacterial properties of ultrafiltration membrane modified by graphene oxide with nano-silver particles. J Colloid Interface Sci 484: 107-115.

160. Liu S, Zeng TH, Hofmann M, Burcombe E, Wei J, et al. (2011) Antibacteria activity of graphite, graphite oxide, graphene oxide, and reduced graphene oxide: Membrane and oxidative stress. ACS Nano 5: 6971-6980.

161. Qian D, Chen D, Li N, Xu Q, Li H, et al. (2018) TiO2/sulfonated graphene oxide/Ag nanoparticle membrane: In situ separation and photodegradation of oil/water emulsions. J Mem Sci 554: 16-25.

162. Fan Y, Quan X, Zhao H, Chen S, Yu H, et al. (2017) Poly (vinylidene fluoride) hollow-fiber membranes containing silver/graphene oxide dope with excellent filtration performance. J Appl Polym Sci 134.

163. Faria AF, Liu C, Xie M, Perreault F, Nghiem LD, et al. (2017) Thin-film composite forward osmosis membranes functionalized with graphene oxidesilver nanocomposites for biofouling control. J Mem Sci 525: 146-156.

164. Kumar M, Gholamvand Z, Morrissey A, Nolan K, Ulbricht M, et al. (2016) Preparation and characterization of low fouling novel hybrid ultrafiltration membranes based on the blends of GO-TiO2 nanocomposite and polysulfone for humic acid removal. J Mem Sci 506: 38-49.

165. Jin L, Wang Z, Zheng S, Mi B (2018) Polyamide-crosslinked graphene oxide membrane for forward osmosis. J Mem Sci 545: 11-18.

166. Zhang C, Wei K, Zhang W, Bai Y, Sun Y, et al. (2017) Graphene oxide quantum dots incorporated into a thin film nanocomposite membrane with high flux and antifouling properties for low-pressure nanofiltration. ACS Appl Mater Interfaces 9: 11082-11094.

167. Kim S, Lin X, Ou R, Liu H, Zhang X, et al. (2017) Highly crosslinked, chlorine tolerant polymer network entwined graphene oxide membrane for water desalination. J Mater Chem 5: 1533-1540.

168. de Faria AF, de Moraes ACM, Andrade PF, da Silva DS, do Carmo Gonçalves
$M$ et al (2017) Cellulose acetate membrane embedded with graphene oxidesilver nanocomposites and its ability to suppress microbial proliferation. Cellulose 24: 781-796.

169. Kochameshki MG, Marjani A, Mahmoudian M, Farhadi K (2017) Grafting of diallyldimethylammonium chloride on graphene oxide by raft polymerization for modification of nanocomposite polysulfone membranes using in water treatment. Chemical Engineering Journal 309: 206-221.

170.Lim S, Park MJ, Phuntsho S, Tijing LD, Nisola GM, et al. (2017) Dual-layered nanocomposite substrate membrane based on polysulfone/graphene oxide for mitigating internal concentration polarization in forward osmosis. Polymer 110 : 36-48.

171.Wang J, Wang Y, Zhu J, Zhang Y, Liu J, et al. (2017) Construction of TiO2@ graphene oxide incorporated antifouling nanofiltration membrane with elevated filtration performance. J Mem Sci 533: 279-288.

172. Xu H, Ding M, Liu S, Li Y, Shen Z, et al. (2017) Preparation and characterization of novel polysulphone hybrid ultrafiltration membranes blended with n-doped GO/TiO2 nanocomposites. Polymer 117: 198-207.

173. Li A, Han K, Zhou Y, Ye H, Liu G, et al. (2017) Incorporating multivalent metal cations into graphene oxide: Towards highly-aqueous-stable free-standing membrane via vacuum filtration with polymeric filters. Mater Today Commun 11: 139-146.

174. Ma X, Su Y, Sun Q, Wang Y, Jiang Z (2007) Enhancing the antifouling property of polyethersulfone ultrafiltration membranes through surface adsorptioncrosslinking of poly (vinyl alcohol). J Mem Sci 300: 71-78.

175. Boricha AG, Murthy Z (2008) Preparation and performance of N, O carboxymethyl chitosan-polyether sulfone composite nanofiltration membrane in the separation of nickel ions from aqueous solutions. J Appl Polym Sci 110: 3596-3605.

176. Zhao X, Chen W, Su Y, Zhu W, Peng J, et al. (2013) Hierarchically engineered membrane surfaces with superior antifouling and self-cleaning properties. Mem Sci 441: 93-101.

177. Song H, Yu H, Zhu L, Xue L, Wu D, et al. (2017) Durable hydrophilic surface modification for PTFE hollow fiber membranes. React Funct Polym 114: 110-117.

178. Shen L, Feng S, Li J, Chen J, Li F, et al. (2017) Surface modification of polyvinylidene fluoride (PVDF) membrane via radiation grafting: Nove mechanisms underlying the interesting enhanced membrane performance. Sci Rep 7: 2721.

179.Zhu L, Song H, Zhang D, Wang G, Zeng Z, et al. (2017) Negatively charged polysulfone membranes with hydrophilicity and antifouling properties based on in situ cross-linked polymerization. J Colloid Interface Sci 498: 136-143.

180. Kirschner AY, Chang CC, Kasemset S, Emrick T, Freeman BD (2017) Foulingresistant ultrafiltration membranes prepared via co-deposition of dopamine/ zwitterion composite coatings. J Mem Sci 541: 300-311

181. Wan P, Bernards MT, Deng B (2017) Modification of Polysulfone (PSF) hollow fiber membrane (HFM) with zwitterionic or charged polymers. Ind Eng Chem Res 56: 7576-7584.

182. Bucs SS, Linares VR, Farhat N, Matin A, Khan Z, et al. (2017) Coating of reverse osmosis membranes with amphiphilic copolymers for biofouling control. Desalination and Water Treatment 68: 1-11.

183. Wang Y, Wang Z, Han X, Wang J, Wang S (2017) Improved flux and antibiofouling performances of reverse osmosis membrane via surface layer-bylayer assembly. Journal of Membrane Science 539: 403-411.

184. Mural PKS, Jain S, Madras G, Bose S (2017) Antibacterial membranes for water remediation with controlled leaching of biocidal silver aided by prior grafting of poly (ethylene imine) on to ozone-treated polyethylene. Chemistry Select 2: 624-631.

185. McCloskey BD, Park HB, Ju H, Rowe BW, Miller DJ, et al. (2012) A bioinspired fouling-resistant surface modification for water purification membranes. J Mem Sci 413: 82-90.

186.Zhao YF, Zhu LP, Yi Z, Zhu BK, Xu YY (2013) Improving the hydrophilicity and fouling-resistance of polysulfone ultrafiltration membranes via surface zwitterionicalization mediated by polysulfone-based triblock copolymer additive. J Mem Sci 440: 40-47.

187.Fang X, Li J, Li X, Pan S, Sun X, et al. (2017) Iron-tannin-framework complex 
modified PES ultrafiltration membranes with enhanced filtration performance and fouling resistance. J Col Interface Sci 505: 642-652

188.Zhang J, Wang Z, Liu M, Zhao F, Wu Z (2017) In-situ modification of PVDF membrane during phase-inversion process using carbon nanosphere sol as coagulation bath for enhancing anti-fouling ability. J Mem Sci 526: 272-280.

189. Kaner P, Rubakh E, Asatekin A (2017) Zwitterion-containing polymer additives for fouling resistant ultrafiltration membranes. J Mem Sci 533: 141-159.

190. Roy K, Anjali T, Sujith A (2017) Poly (vinyl chloride) asymmetric membrane modified with poly (ethylene glycol): Effect of additive concentration on the morphology and performance. Poly-Plast Tech Eng 56: 1017-1025.

191.Zhang J, Wang Q, Wang Z, Zhu C, Wu Z (2014) Modification of poly (vinylidene fluoride)/polyethersulfone blend membrane with polyvinyl alcohol for improving antifouling ability. J Mem Sci 466: 293-301.

192. Fan X, Su Y, Zhao X, Li Y, Zhang R, et al. (2014) Fabrication of polyviny chloride ultrafiltration membranes with stable antifouling property by exploring the pore formation and surface modification capabilities of polyvinyl formal. $J$ Mem Sci 464: 100-109.

193. Razzaghi MH, Safekordi A, Tavakolmoghadam M, Rekabdar F, Hemmati M (2014) Morphological and separation performance study of pvdf/ca blend membranes. J Mem Sci470: 547-557.

194. Son M, Kim H, Jung J, Jo S, Choi H (2017) Influence of extreme concentrations of hydrophilic pore-former on reinforced polyethersulfone ultrafiltration membranes for reduction of humic acid fouling. Chemosphere 179: 194-201.

195. Lakshmi DS, Jaiswar S, Tasselli F, Raval HD (2017) Preparation and performance of biofouling resistant PAN/chitosan hollow fiber membranes. 3 Biotech 7: 224.

196. Liu Y, Su Y, Li Y, Zhao X, Jiang Z (2015) Improved antifouling property of PVDF membranes by incorporating an amphiphilic block-like copolymer for oil/water emulsion separation. RSC Advances 5: 21349-21359.

197. You X, Ma T, Su Y, Wu H, Wu M, et al. (2017) Enhancing the permeation flux and antifouling performance of polyamide nanofiltration membrane by incorporation of PEG-POSS nanoparticles. J Mem Sci 540: 454-463.

198. Zhang Y, Li H, Li H, Li R, Xiao C (2006) Preparation and characterization of modified polyvinyl alcohol ultrafiltration membranes. Desalination 192: 214-223.

199. Zhu J, Su Y, Zhao X, Li Y, Zhao J, et al. (2014) Improved antifouling properties of poly (vinyl chloride) ultrafiltration membranes via surface zwitterionicalization. Ind Eng Chem Res 53: 14046-14055.

200.Sun C, Feng X (2017) Enhancing the performance of PVDF membranes by hydrophilic surface modification via amine treatment. Separation and Purification Technology 185: 94-102.

201. Berbar Y, Amara M, Ammi-Said A, Yuan S, Van der Bruggen B (2017) New method for silica embedding on a PES membrane surface via in situ sol gel process and immobilization in a polyamide thin film composite. J Env Chem Eng 5: 3604-3615

202. Yu LY, Xu ZL, Shen HM, Yang H (2009) Preparation and characterization of PVDF-SiO2 composite hollow fiber UF membrane by sol-gel method. J Mem Sci 337: 257-265

203.Xu HP, Yu YH, Lang WZ, Yan X, Guo YJ (2015) Hydrophilic modification of polyvinyl chloride hollow fiber membranes by silica with a weak in situ sol-gel method. RSC Adv 5: 13733-13742.

204. Yang Y, Wang P (2006) Preparation and characterizations of a new PS/ TiO2 hybrid membranes by sol-gel process. Polymer 47: 2683-2688.

205. Liu X, Peng Y, Ji S (2008) A new method to prepare organic-inorganic hybrid membranes. Desalination 221: 376-382.

206. Gebru KA, Das C (2017) Removal of bovine serum albumin from wastewater using fouling resistant ultrafiltration membranes based on the blends of cellulose acetate, and PVP-TiO2 nanoparticles. J Environ Management 200: 283-294.

207. Lai G, Yusob M, Lau W, Gohari RJ, Emadzadeh D, et al. (2017) Novel mixed matrix membranes incorporated with dual-nanofillers for enhanced oil-water separation. Sep Pur Tech 178: 113-121.
208. Rahmati NO, Chenar MP, Namaghi HA (2017) Removal of free active chlorine from synthetic wastewater by MEUF process using polyethersulfone/titania nanocomposite membrane. Sep Pur Tech 181: 213-222.

209. Shen X, Xie T, Wang J, Liu P, Wang F (2017) An anti-fouling poly (vinylidene fluoride) hybrid membrane blended with functionalized $\mathrm{ZrO} 2$ nanoparticles for efficient oil/water separation. RSC Adv 7: 5262-5271.

210.Pang R, Li X, Li J, Lu Z, Sun X, et al. (2014) Preparation and characterization of $\mathrm{ZrO} 2 / \mathrm{PES}$ hybrid ultrafiltration membrane with uniform $\mathrm{ZrO} 2$ nanoparticles. Desalination 332: 60-66.

211. Rabiee H, Vatanpour V, Farahani MHDA, Zarrabi H (2015) Improvement in flux and antifouling properties of PVC ultrafiltration membranes by incorporation of zinc oxide (ZnO) nanoparticles. Sep Pur Tech 156: 299-310.

212. Rajeswari A, Vismaiya S, Pius A (2017) Preparation, characterization of nano $\mathrm{ZnO}$-blended cellulose acetate-polyurethane membrane for photocatalytic degradation of dyes from water. Chemical Engineering Journal 313: 928-937.

213. Hong J, He Y (2014) Polyvinylidene fluoride ultrafiltration membrane blended with nano-ZnO particle for photo-catalysis self-cleaning. Desalination 332: $67-75$.

214. Al-Hinai MH, Sathe P, Al-Abri MZ, Dobretsov S, Al-Hinai AT, et al. (2017) Antimicrobial activity enhancement of poly (ether sulfone) membranes by in situ growth of ZnO nanorods. ACS Omega 2: 3157-3167.

215. Lin Y, Loh CH, Shi L, Fan Y, Wang R (2017) Preparation of high-performance Al2O3/PES composite hollow fiber UF membranes via facile in-situ vapor induced hydrolyzation. J Mem Sci 539: 65-75.

216. Yan L, Hong S, Li ML, Li YS (2009) Application of the Al2O3-PVDF nanocomposite tubular ultrafiltration (UF) membrane for oily wastewater treatment and its antifouling research. Separation and Purification Technology 66: 347-352.

217. Mokhtari S, Rahimpour A, Shamsabadi AA, Habibzadeh S, Soroush M (2017) Enhancing performance and surface antifouling properties of polysulfone ultrafiltration membranes with salicylate-alumoxane nanoparticles. App Surf Sci 393: 93-102.

218. Ng LY, Leo CP, Mohammad AW (2011) Optimizing the incorporation of silica nanoparticles in polysulfone/poly (vinyl alcohol) membranes with response surface methodology. J App Poly Sci 121: 1804-1814.

219. Jadav GL, Singh PS (2009) Synthesis of novel silica-polyamide nanocomposite membrane with enhanced properties. J Mem Sci 328: 257-267.

220. Mosafer A, Toosi M, Asghari M (2017) Effect study of hexagonal mesoporous silica/polyaniline nanocomposite on the structural properties of polysulfone membranes and its heavy metal removal efficiency. Sep Sci Tech 52: 17751786.

221. Ghaemi N, Madaeni SS, Daraei P, Rajabi H, Zinadini S, et al. (2015) Polyethersulfone membrane enhanced with iron oxide nanoparticles for copper removal from water: Application of new functionalized $\mathrm{Fe} 3 \mathrm{O} 4$ nanoparticles. Chemical Engineering Journal 263: 101-112.

222. Gholami A, Moghadassi A, Hosseini S, Shabani S, Gholami F (2014) Preparation and characterization of polyvinyl chloride based nanocomposite nanofiltration-membrane modified by iron oxide nanoparticles for lead removal from water. Journal of Industrial and Engineering Chemistry 20: 1517-1522.

223. Dasgupta J, Chakraborty S, Sikder J, Kumar R, Pal D, et al. (2014) The effects of thermally stable titanium silicon oxide nanoparticles on structure and performance of cellulose acetate ultrafiltration membranes. Sep Pur Tech 133: $55-68$.

224. Li JH, Shao XS, Zhou Q, Li MZ, Zhang QQ (2013) The double effects of silver nanoparticles on the PVDF membrane: Surface hydrophilicity and antifouling performance. App Surf Sci 265: 663-670.

225. Lee SY, Kim HJ, Patel R, Im SJ, Kim JH, et al. (2007) Silver nanoparticles immobilized on thin film composite polyamide membrane: Characterization, nanofiltration, antifouling properties. Poly Adv Tech 18: 562-568.

226. Vatanpour V, Zoqi N (2017) Surface modification of commercial seawater reverse osmosis membranes by grafting of hydrophilic monomer blended with carboxylated multiwalled carbon nanotubes. App Surf Sci 396: 1478-1489.

227. Fan Y, Quan X, Zhao H, Chen S, Yu H, et al. (2017) Poly (vinylidene fluoride) hollow-fiber membranes containing silver/graphene oxide dope with excellent filtration performance. J App Poly Sci 134: 44713. 
Citation: Zahid M, Rashid A, Akram S, Rehan ZA, Razzaq W (2018) A Comprehensive Review on Polymeric Nano-Composite Membranes for Water Treatment. J Membr Sci Technol 8: 179. doi:10.4172/2155-9589.1000179

228. Zheng J, Li M, Yu K, Hu J, Zhang X, et al. (2017) Sulfonated multiwall carbon nanotubes assisted thin-film nanocomposite membrane with enhanced water flux and anti-fouling property. J Mem Sci 524: 344-353.

229. Yang E, Kim CM, Song J, Ki H, Ham MH, et al. (2017) Enhanced desalination performance of forward osmosis membranes based on reduced graphene oxide laminates coated with hydrophilic polydopamine. Carbon 117: 293-300.

230.Zhang X, Wang Z, Chen M, Ma J, Chen S, et al. (2017) Membrane biofouling control using polyvinylidene fluoride membrane blended with quaternary ammonium compound assembled on carbon material. J Mem Sci 539: 229-237.

231. Farahani MHDA, Hua D, Chung TS (2017) Cross-linked mixed matrix membranes consisting of carboxyl-functionalized multi-walled carbon nanotubes and P84 polyimide for organic solvent nanofiltration (OSN). Sep Purif Tech 186: 243-254.

232. Al Amer AM, Laoui T, Abbas A, Al-Aqeeli N, Patel F, et al. (2016) Fabrication and antifouling behaviour of a carbon nanotube membrane. Materials \& Design 89: 549-558

233. Wang H, Wang W, Wang L, Zhao B, Zhang Z, et al. (2018) Enhancement of hydrophilicity and the resistance for irreversible fouling of Polysulfone (PSf) membrane immobilized with graphene oxide (GO) through chloromethylated and quaternized reaction. Chemical Engineering Journal 334: 2068-2078.

234.Xia S, Ni M (2015) Preparation of poly (vinylidene fluoride) membranes with graphene oxide addition for natural organic matter removal. J Mem Sci 473 : $54-62$.
235. Li X, Zhao C, Yang M, Yang B, Hou D, et al. (2017) Reduced graphene oxide-NH2 modified low pressure nanofiltration composite hollow fiber membranes with improved water flux and antifouling capabilities. App Surf Sci 419: 418-428.

236.Zinadini S, Rostami S, Vatanpour V, Jalilian E (2017) Preparation of antibiofouling polyethersulfone mixed matrix NF membrane using photocatalytic activity of ZnO/MWCNTS nanocomposite. J Mem Sci 529: 133-141.

237.Zhang J, Chen N, Su P, Li M, Feng C (2017) Fluoride removal from aqueous solution by zirconium-chitosan/graphene oxide membrane. React Funct Polym 114: 127-135.

238.Zambare RS, Dhopte KB, Patwardhan AV, Nemade PR (2017) Polyamine functionalized graphene oxide polysulfone mixed matrix membranes with improved hydrophilicity and anti-fouling properties. Desalination 403: 24-35.

239. Yin J, Zhu G, Deng B (2013) Multi-walled carbon nanotubes (MWNTS)/ Polysulfone (PSU) mixed matrix hollow fiber membranes for enhanced wate treatment. J Mem Sci 437: 237-248.

240. Vatanpour V, Esmaeili M, Farahani MHDA (2014) Fouling reduction and retention increment of polyethersulfone nanofiltration membranes embedded by amine-functionalized multi-walled carbon nanotubes. J Mem Sci 466: 70-81.

241. Vatanpour V, Madaeni SS, Moradian R, Zinadini S, Astinchap B (2011) Fabrication and characterization of novel antifouling nanofiltration membrane prepared from oxidized multiwalled carbon nanotube/polyethersulfone nanocomposite. J Mem Sci 375: 284-294. 